\title{
THEMATIC REVIEW
}

\section{Deiodinases: the balance of thyroid hormone}

\section{Type 1 iodothyronine deiodinase in human physiology and disease}

\author{
Ana Luiza Maia, luri Martin Goemann, Erika L Souza Meyer and Simone Magagnin Wajner \\ Endocrine Division, Thyroid Section, Serviço de Endocrinologia, Hospital de Clínicas de Porto Alegre, Universidade Federal do Rio Grande do Sul, Rua Ramiro \\ Barcelos, 2350, CEP 90035-003 Porto Alegre, RS, Brazil \\ (Correspondence should be addressed to A L Maia; Email: almaia@ufrgs.br)
}

\begin{abstract}
Thyroid hormone is essential for the normal function of virtually all tissues. The iodothyronine deiodinases catalyze the removal of an iodine residue from the pro-hormone thyroxine $\left(T_{4}\right)$ molecule, thus producing either the active form triiodothyronine $\left(\mathrm{T}_{3}\right.$; activation) or inactive metabolites (reverse $\mathrm{T}_{3}$; inactivation). Type I deiodinase (D1) catalyzes both reactions. Over the last years, several studies have attempted to understand the mechanisms of D1 function, underlying its effects on normal thyroid hormone metabolism and pathological processes. Although peripheral D1-generated $\mathrm{T}_{3}$ production contributes to a portion of plasma $T_{3}$ in euthyroid state, pathologically increased thyroidal D1 activity seems to be the main cause of the elevated $T_{3}$ concentrations
\end{abstract}

observed in hyperthyroid patients. On the other hand, D1-deficient mouse models show that, in the absence of D1, inactive and lesser iodothyronines are excreted in feces with the loss of associated iodine, demonstrating the scavenging function for D1 that might be particularly important in an iodine deficiency setting. Polymorphisms in the DIO1 gene have been associated with changes in serum thyroid hormone levels, whereas decreased D1 activity has been reported in the nonthyroid illness syndrome and in several human neoplasias. The current review aims at presenting an updated picture of the recent advances made in the biochemical and molecular properties of D1 as well as its role in human physiology.

Journal of Endocrinology (2011) 209, 283-297

\section{Introduction}

Thyroid hormones are critical to the development and metabolism of virtually all tissues. Although the human thyroid gland mainly secretes thyroxine $\left(T_{4}\right)$, thyroid hormone actions are mediated by the active hormone, triiodothyronine $\left(\mathrm{T}_{3}\right)$. In euthyroid individuals, the conversion of peripheral $\mathrm{T}_{4}$ to $\mathrm{T}_{3}$ accounts for $80 \%$ of all the $\mathrm{T}_{3}$ produced. This critical step in thyroid hormone metabolism is catalyzed by two enzymes, the type 1 and type 2 iodothyronine deiodinases (D1 and D2), via outer $\left(5^{\prime}\right)$-ring deiodination of the pro-hormone $\mathrm{T}_{4}$. Type 3 iodothyronine deiodinase (D3) catalyzes the inner (5)-ring deiodination of $\mathrm{T}_{4}$ and $\mathrm{T}_{3}$, thus inactivating the thyroid hormone action.

In the last decades, several studies have extended our understanding on the mechanisms of D1 function in humans, underlying its effects on normal hormone metabolism and

This paper is one of 3 papers that form part of a Thematic review section on deiodinases: the balance of thyroid hormone. The Guest Editor for this section was Domenico Salvatore, University of Naples, Italy. pathological processes. D1 is the only selenodeiodinase that can function as either an outer- $\left(5^{\prime}\right)$ or an inner (5)-ring iodothyronine deiodinase and was the first to be cloned (Berry et al. 1991a, Mandel et al. 1992). D1 is believed to provide a significant portion of the circulating plasma $T_{3}$ in euthyroid vertebrates, including humans. Nevertheless, the remarkable preference of D1 for reverse $\mathrm{T}_{3}\left(\mathrm{rT}_{3}\right)$ as the enzymatic outer-ring deiodination substrate, as well as the deiodination of sulfated iodothyronines, argues for its role as a scavenger enzyme to deiodinate inactive iodothyronines, thus clearing these compounds from the circulation and serving, if necessary, to recycle iodine within the organism (Schneider et al. 2006). More recently, attention has been turned to the role of D1 in the biosynthesis of thyronamines, a newly identified class of endogenous compounds that appears to antagonize thyroid hormone actions (Scanlan et al. 2004).

The genetic background influences serum thyroid hormone profile. Single nucleotide polymorphisms (SNPs) in the deiodinase genes may interfere in the phenotypic expression of these enzymes influencing the levels of thyroid hormone. Indeed, several SNPs have been identified in the DIO1 gene and associated with changes in circulating thyroid hormone 
levels. Of note, it is remarkable that no inherited deficiency or mutation in human deiodinase genes has been reported so far. Pathologically increased thyroidal D1 activity plays a key role in the elevated serum $\mathrm{T}_{3}$ concentrations observed in hyperthyroid patients. Conversely, impaired D1 activity is likely to contribute to the lower levels of serum $T_{3}$ in the nonthyroid illness syndrome. Because thyroid hormone influences the vital balance between cell proliferation and differentiation, deiodinases might also play a role in controlling the intracellular levels of thyroid hormone levels in tumorigenesis. Decreased DIO1 expression has been suggested as a marker of the epithelial follicular thyroid cell dedifferentiation, and even though the reasons for that remain speculative, it is striking that lower D1 expression has been described in almost all tumors derived from parenchymal or epithelial tissues.

This review aims at presenting an updated picture of the recent advances of our knowledge regarding the role of deiodinase type 1 as a regulator of thyroid hormone metabolism in human physiology and disease.

\section{Genetic, biochemical, and molecular properties of type 1 deiodinase}

The human DIO1 gene is located in the p32-p33 region on chromosome 1 and consists of four exons (Jakobs et al. 1997a). The mRNA size is about $2-2 \cdot 1 \mathrm{~kb}$ with a UGA selenocysteine $(\mathrm{Sec})$ codon in the region encoding the active center (Berry et al. 1991b). The TGA codon for the incorporation of Sec is located on the second exon (Mandel et al. 1992, Jakobs et al. 1997b). The encoded $27 \mathrm{kDa} \mathrm{D} 1$ protein is highly similar in size (26-30 kDa) and sequence among species with a few informative exceptions (Berry et al. 1991a,b, Mandel et al. 1992, Maia et al. 1995a, Sanders et al. 1997). The D1 protein contains a critical Sec residue at position 126 and is exquisitely sensitive to inhibition by propylthiouracil (6-n-propyl-2thiouracil, PTU; Mandel et al. 1992). The human DIO1 gene is under the control of GC-rich SP1 promoters and contains two thyroid hormone response elements (TREs), both contributing to the $\mathrm{T}_{3}$ responsiveness of the human DIO1 promoter (Toyoda et al. 1995, Zhang et al. 1998).

In vertebrates, D1 is mainly expressed in liver and kidney, whereas in adult mammals, the Dio1 transcripts are also identified in thyroid, pituitary gland, intestine, placenta, and gonads (St Germain \& Galton 1997, Bates et al. 1999, Wagner et al. 2008). An interesting study that evaluated the expression profile of all three deiodinases in a wide spectrum of rat tissues showed that D1 is the only deiodinase expressed in liver, kidney, and intestine at all stages of development (Bates et al. 1999). Both D1 mRNA and activity are present at low levels during fetal development and increase at later life stages, suggesting that D1 expression is regulated at least in part at a pretranslational level. The only exception for this expression pattern seems to be the testis, which presents higher levels of D1 activity in neonatal and weanling life (Bates et al. 1999, Wagner et al. 2008). Data on the ontogeny of the deiodinases in human fetal tissues are limited. On the basis of high levels of $\mathrm{rT}_{3}$ and $\mathrm{T}_{3}$ sulfate $\left(\mathrm{T}_{3} \mathrm{~S}\right)$ observed in the human fetus, low levels of D1 activity are predicted, which progressively increase during the late gestational period and after birth (Santini et al. 1999). Indeed, hepatic D1 expression has been detected in the second gestational trimester at similar levels as observed in newborns, being around $20 \%$ of that found in adult liver (Huang et al. 1988, Richard et al. 1998). Of note, D1 is undetectable in human fetal brain tissues (Kester et al. 2004).

D1 is a thioredoxin (Trx)-fold integral membrane protein with a single transmembrane segment presented in the N-terminus and several clusters, corresponding to core secondary structures that compose the deiodinase globular domains (Callebaut et al. 2003). Studies using confocal microscopy of transiently expressed D1 in the human embryonic kidney cell line (HEK-293) indicate that it is localized in the plasma membrane with a cytosolic catalytic site (Baqui et al. 2000). The half-life of D1 protein is $>12 \mathrm{~h}$ and its inactivation and subsequent degradation is enhanced by substrates such as iopanoic acid or $\mathrm{rT}_{3}$ but is apparently not

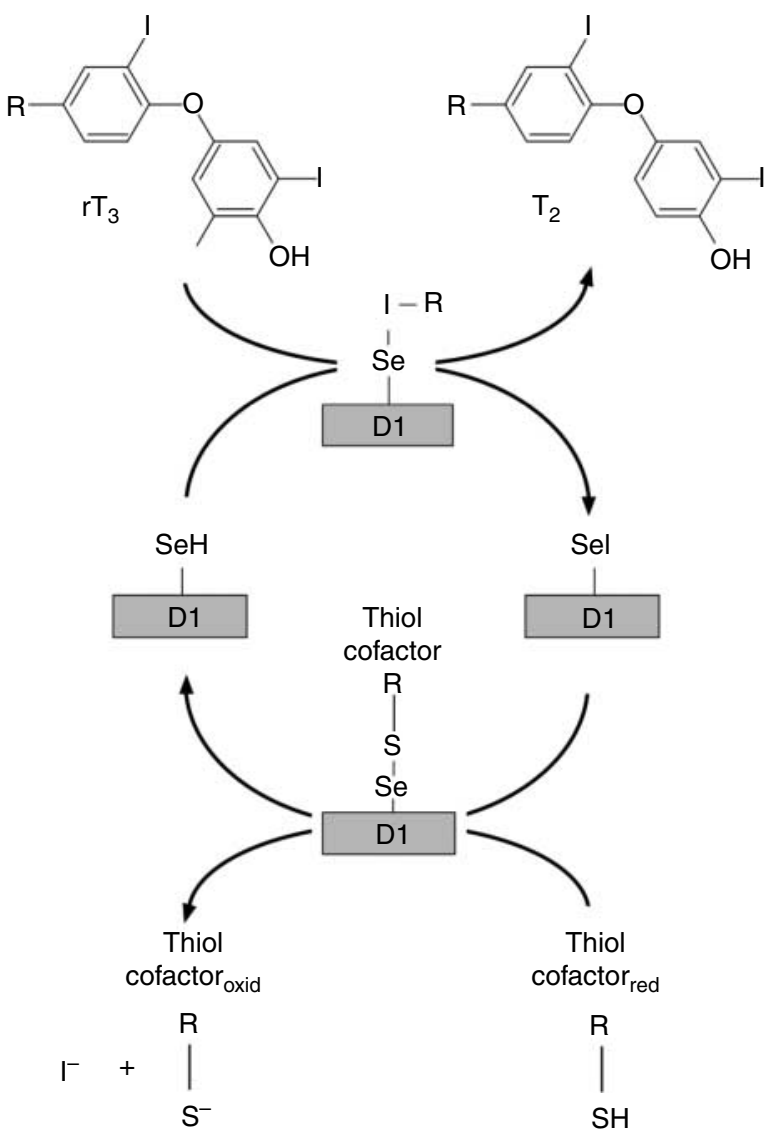

Figure 1 Schematic model of thyroid hormone catalysis by type 1 deiodinase. D1-catalyzed reaction follows ping-pong kinetics with two substrates: the first being an iodothyronine and the second being an as yet unidentified endogenous intracellular thiol cofactor. $\mathrm{rT}_{3}, 3,3^{\prime}, 5^{\prime}$-triiodothyronine; $\mathrm{T}_{2}$, diiodothyronine; $\mathrm{D} 1$, deiodinase type 1 ; Se, selenium; I, iodide. 
susceptible to ubiquitination (St Germain 1988, St Germain \& Croteau 1989, Gereben et al. 2000). It is still unclear whether the inactivated D1 can be reactivated in vivo, but continued protein synthesis is probably required for the maintenance of D1 activity. As shown in Fig. 1, D1-catalyzed reaction follows ping-pong kinetics with two substrates: the first being the iodothyronine and the second being an as yet unidentified endogenous intracellular thiol cofactor (Visser et al. 1976, 1978, Chopra et al. 1978, Leonard \& Rosenberg 1980, Berry et al. 1991c). The catalytic cycle of D1 comprises two half reactions: first, there is transference of $\mathrm{I}^{+}$from the substrate to selenolate $\left(\mathrm{Se}^{-}\right)$, resulting in an intermediate compound that is immediately reduced by the cofactor generating a selenium iodide (SeI) complex. The proposed mechanism of the enzymatic reaction for the D1 enzyme involves the interaction of the sulfhydryl group of the enzyme cysteine (Cys) residue with the second substrate. In this case, the as yet undefined cofactor would act as a reducing agent releasing iodine from the $\mathrm{Sec}$ residue and regenerating the active enzyme (Goswami \& Rosenberg 1984, Berry et al. 1991c, Sun et al. 1997). Early studies on the D1-catalyzed reaction suggested that the endogenous cofactor might be glutathione $(\mathrm{GSH})$ or Trx because both were effective in supporting catalysis (Goswami \& Rosenberg 1987, St Germain 1988, Sharifi \& St Germain 1992). PTU, a potent uncompetitive D1 inhibitor, is thought to react with the SeI intermediate by competing with the thiol cosubstrate to form an essentially irreversible complex (Sharifi \&
St Germain 1992). On the other hand, gold and iopanoic acid are competitive inhibitors of the D1 deiodination reaction, presumably interacting with the selenium in the active center (Berry et al. 1991c, Mandel et al. 1992). As expected for an enzymatic reaction, the D1-catalyzed deiodination for both the outer and the inner ring of $\mathrm{T}_{4}$ is influenced by $\mathrm{pH}$ (Visser et al. 1979, Leonard \& Visser 1986).

A remarkable feature of $\mathrm{D} 1$ is its higher preference for $\mathrm{rT}_{3}$ as the enzymatic outer-ring deiodination substrate, as well as the deiodination of sulfated iodothyronines (Otten et al. 1983, Visser et al. 1988, Toyoda et al. 1997). Inner-ring deiodination of $\mathrm{T}_{3} \mathrm{~S}$ by human and rat $\mathrm{D} 1$ is nearly 40 times faster than that from $\mathrm{T}_{3}$ (Otten et al. 1984). The same is observed for $\mathrm{T}_{4} \mathrm{~S}$ and $\mathrm{T}_{2} \mathrm{~S}$. Of interest, $\mathrm{T}_{4}$ can serve as a substrate for the induced low $K_{\mathrm{m}}$ processes, but, in this case, $K_{\mathrm{m}}$ values were dependent on the artificial cofactor (dithiothreitol, DTT) concentrations (Sharifi \& St Germain 1992). Conjugation of the phenolic hydroxyl with sulfate markedly enhances the suitability of the iodothyronine substrates for D1-catalyzed $5^{\prime}$ deiodination (Otten et al. 1983, Mol \& Visser 1985). This is reflected in a markedly higher $V_{\max } / K_{\mathrm{m}}$ ratio for those substrates. Sulfation of $\mathrm{T}_{3}$ also clearly enhances the inner-ring deiodination, but the preference of $\mathrm{D} 1$ for $\mathrm{T}_{3} \mathrm{~S}$ is much lower than that for $\mathrm{rT}_{3}$ or $\mathrm{rT}_{3} \mathrm{~S}$. The rate-limiting steps in the sulfation or desulfation of iodothyronines in a given tissue should be kept in mind when trying to predict the effects of D1-catalyzed deiodination.

Table 1 summarizes molecular and biochemical characteristics of the human D1.

Table 1 Molecular and biochemical properties of the human type 1 deiodinase

\begin{tabular}{|c|c|}
\hline Parameter & Property \\
\hline Reaction catalyzed & 5- or 5'-deiodination \\
\hline Chromosomal location & 1 p32-p33 \\
\hline Molecular mass & $28 \cdot 3 \mathrm{kDa}$ \\
\hline Subcellular location & $\begin{array}{l}\text { Plasma membrane with the } \\
\text { catalytic center in the inner surface }\end{array}$ \\
\hline Substrate preference & $\begin{array}{l}\mathrm{rT}_{3}>\mathrm{T}_{2} \mathrm{~S} \gg \mathrm{T}_{4}\left(5^{\prime}\right) \\
\mathrm{T}_{4} \mathrm{~S}>\mathrm{T}_{2} \mathrm{~S}>\mathrm{T}_{3} \mathrm{~T}_{4}(5)\end{array}$ \\
\hline$K_{\mathrm{m}}{ }^{\mathrm{a}}$ & $\begin{array}{l}\mathrm{rT}_{3}\left(5^{\prime}\right): 0 \cdot 21 \mu \mathrm{M} \\
\mathrm{T}_{3}(5): 2 \cdot 8 \mu \mathrm{M} \\
\mathrm{T}_{4}\left(5^{\prime}\right): 1 \cdot 9 \mu \mathrm{M}\end{array}$ \\
\hline Cofactor & $\begin{array}{l}\text { Endogenous: unknown } \\
\text { Artificial: dithiothreitol (DTT) }\end{array}$ \\
\hline $\begin{array}{l}\text { Tissue distribution } \\
\text { Inhibitors }\end{array}$ & Liver, kidney, thyroid, and pituitary \\
\hline PTU & Uncompetitive inhibition \\
\hline $\begin{array}{l}\text { Gold and iopanoic acid } \\
\text { Regulatory factors }\end{array}$ & Competitive inhibition \\
\hline Upregulation & $\mathrm{T}_{3}$ \\
\hline & $\begin{array}{l}\text { TSH } \\
\text { Retinoic acid } \\
\text { cAMP } \\
\text { GH }\end{array}$ \\
\hline Down regulation & Selenium deficiency \\
\hline
\end{tabular}

${ }_{5} \mathrm{mM}$ DTT.

\section{References}

Jakobs et al. (1997a)

Mandel et al. (1992)

Baqui et al. (2000)

Otten et al. (1983, 1984) and Toyoda et al. (1997)

Visser et al. (1988)

Mandel et al. (1992) and Santini et al. (1999)

Berry et al. (1991c) and Mandel et al. (1992)

Toyoda et al. (1995), Jakobs et al. (1997b) and

Zhang et al. (1998)

Ishii et al. (1983) and Beech et al. (1995)

Schreck et al. (1994) and Toyoda et al. (1995)

Beech et al. (1995)

Jorgensen et al. (1989) and Alcantara et al. (2006)

Corvilain et al. (1993) and Duntas (2010) 


\section{Regulation of type 1 iodothyronine deiodinase expression}

The expression and activity of D1 are modulated by a variety of hormonal, nutritional, and developmental factors, the most potent being thyroid hormone (Harris et al. 1978, Kaplan \& Utiger 1978, Maia et al. 1995b, Koenig 2005). The $\mathrm{T}_{3}$ effect in rat and mouse Dio1 gene is due to transcriptional activation and does not require protein synthesis (Berry et al. 1990, Maia et al. 1995c). $\mathrm{T}_{3}$ also positively regulates the human DIO1 gene at the transcriptional levels by interaction with two complex TREs located in the promoter region (Toyoda et al. 1995, Jakobs et al. 1997b, Zhang et al. 1998). In addition, the human DIO1 promoter contains thyroid hormone responseretinoic acid (RA) response elements that mediate thyroid hormone receptor (TR) $\beta$ activation (Schreck et al. 1994, Toyoda et al. 1995). Interestingly, a recent report indicates that, in mice, the promoter of the Dio1 gene is also regulated by the hepatocyte nuclear factor $4 \alpha$ (HNF4 $\alpha$; Ohguchi et al. 2008). Based on the findings of that study, HNF $4 \alpha$ would play a role in thyroid hormone homeostasis by cooperatively regulating the $5^{\prime}$-deiodination of $\mathrm{T}_{4}$ with GATA4 and $\mathrm{T}_{3}$-inducible Krüppel-like transcription factor 9 (KLF9). The authors also suggest that the $T_{3}$ regulation of Dio 1 gene is probably due to an indirect mechanism that involves the $\mathrm{T}_{3}$-dependent stimulation of KLF9 expression (Ohguchi et al. 2008).

In addition to thyroid hormones, other physiological compounds modulate D1 expression (Table 1). The administration of $\mathrm{GH}$ to euthyroid adults is known to increase the ratio of plasma $T_{3}$ to $T_{4}$ whereas reducing that of $\mathrm{rT}_{3}$ to $\mathrm{T}_{4}$ (Jorgensen et al. 1989, Alcantara et al. 2006), in a peripheral mechanism that probably involves augmented D1 and/or a reduction in D3 activity (Darras et al. 1992, Van der Geyten et al. 1999). TSH also induces D1 synthesis in the human thyroid gland, by a mechanism that involves, at least in part, the second messenger cAMP, via a protein synthesisdependent process (Ishii et al. 1983, Pekary et al. 1994, Beech et al. 1995). Although the mechanism for the stimulation of Dio 1 transcription by cAMP has not been fully elucidated, its effects are additive to that of $\mathrm{T}_{3}$, resulting in a fivefold stimulation relative to control (Mori et al. 1996).

Data on the effects of glucocorticoids on D1 expression are controversial. Although some in vitro studies have shown that glucocorticoids induce D1 mRNA and activity in rat liver, others described no changes in D1 activity (Menjo et al. 1993, Van der Geyten et al. 2005). Studies using rat liver and kidney cell cultures observed an increase of D1 mRNA and activity after incubation with dexamethasone (Davies et al. 1996b). Controversially, studies on a pituitary rat cell line found that dexamethasone alone had no effect on Dio1 gene expression but did enhance the effect of $\mathrm{T}_{3}$ (Maia et al. 1995b). On the other hand, the administration of dexamethasone to euthyroid adult males increased the circulating $\mathrm{rT}_{3}$ and $\mathrm{rT}_{3} / \mathrm{T}_{4}$ ratios, which could be a result of the augmented production of $\mathrm{rT}_{3}$ instead of decreased clearance (LoPresti et al. 1989).

Deiodinases are selenoproteins and, thus, susceptible to selenium deficiency. The effect of selenium deficiency on the synthesis of intracellular selenoproteins is apparently tissue dependent, being more pronounced in liver, skeletal muscle, and heart (Meinhold et al. 1992, Bermano et al. 1995, Bates et al. 2000). In rats, selenium deficiency decreases D1 activity in liver and kidney by a mechanism that involves protein translation, secondary to a blockage in the Sec incorporation (Beckett et al. 1987, DePalo et al. 1994). The administration of $\mathrm{T}_{3}$ did not affect $\mathrm{D} 1$ activity in the selenium-deficient rats, whereas selenium-fed controls had a twofold increase in enzyme activity. Mice with excessive iodine intake presented a decreased selenium concentration in urine and liver and reduced renal and hepatic D1 mRNA and activity levels (Yang et al. 2006). The selenium supplementation corrected these alterations. In humans, selenium deficiency is observed in subjects receiving diets with restricted protein content, such as those given for phenylketonuria, and also in elderly patients (Kauf et al. 1994, Calomme et al. 1995, Lombeck et al. 1996, Jochum et al. 1997). Seleno-deficient individuals have mildly elevated serum $T_{4}$ and $T_{4}$ to $T_{3}$ ratios, but normal TSH. Indeed, the deficiency of this essential micronutrient has been implicated in the pathogenesis of myxedematous endemic cretinism, prevalent in African endemic goiters, and associated to a thyroid 'exhaustion' atrophy occurring near birth. This might result from the low resistance of a fragile tissue to enhanced $\mathrm{H}_{2} \mathrm{O}_{2}$ generation under intense thyroid stimulation by high TSH levels (Goyens et al. 1987, Vanderpas et al. 1990, Duntas 2010). Of note, deterioration of thyroid function was observed after selenium administration to iodine-deficient people in an African region of endemic goiter, suggesting that the reduction in D1 activity during selenium deficiency can protect against iodine deficiency, presumably by reducing the deiodination of $T_{4}, T_{3}$, or $T_{3} S$ (Contempre et al. 1991, 1992).

\section{Role of D1 deiodinase in thyroid hormone activation and inactivation}

The functional role of D1 in humans remains a matter of debate. Nearly $80 \%$ of peripheral $\mathrm{T}_{3}$ originates from deiodination of the pro-hormone $\mathrm{T}_{4}$ by $\mathrm{D} 1$ and $\mathrm{D} 2$. However, the relative roles of D1 versus D2 in extrathyroidal $\mathrm{T}_{3}$ production are still controversial. Probably because D1 was the first selenodeiodinase to be identified and because of its subcellular location, it was often assumed that the majority of circulating $T_{3}$ was derived from $T_{4}$ via $D 1$ activity. Nevertheless, the long-life of $\mathrm{D} 1$ protein and $\mathrm{T}_{3}$ upregulation of D1 activity, just the opposite of what would be expected in a typical feedback loop, raise some questions about this assumption. Moreover, clinical studies have showed a maximum decrease of $25 \%$ in serum $\mathrm{T}_{3}$ in athyreotic, $\mathrm{T}_{4^{-}}$ replaced, euthyroid individuals treated with higher doses of PTU (Geffner et al. 1975, Saberi et al. 1975). Indeed, subsequent cumulative data on the biochemical and molecular properties of D2 indicate that this enzyme also contributes a significant portion of serum $\mathrm{T}_{3}$ levels in humans 
(Bianco et al. 2005, Maia et al. 2005). The D1 enzyme seems extremely inefficient in carrying out this reaction when compared with the D2, which has a 700-fold greater catalytic efficiency for $5^{\prime}$-deiodination of $\mathrm{T}_{4}$ (Maia et al. 2005). First, in contrast with D2-catalyzed reaction that generates $1 \mathrm{~mol}$ of $\mathrm{T}_{3}$ for each $\mathrm{T}_{4}$ molecule, for each 2 moles of $\mathrm{T}_{4}$ deiodinated by $\mathrm{D} 1$, only $1 \mathrm{~mol}$ of $\mathrm{T}_{3}$ and a second of $\mathrm{rT}_{3}$ is produced since D1 catalyzes the inner- and outer-ring deiodination of $\mathrm{T}_{4}$ equally well, as predicted from $V_{\max } / K_{\mathrm{m}}$ estimates (Visser et al. 1988). This can explain a catalytic efficiency difference of 2 , whereas the rest is primarily due to the much slower rate of D1-catalyzed $T_{4}$ to $T_{3}$ conversion under physiological conditions. This is not easily observed under typical in vitro assay conditions because the catalytic activity of this enzyme significantly varies from the artificial DTT generally used to other cofactor candidates such as GSH, as well as with variations of the cofactor concentrations (Goswami \& Rosenberg 1987, Goemann et al. 2010).

The human $\mathrm{D} 1$ - or $\mathrm{D} 2$-derived $\mathrm{T}_{3}$ production significantly varies according to the thyroid status. Because DIO1 expression is positively regulated by thyroid hormone, D1-catalyzed $T_{4}$ to $T_{3}$ reaction is expected to be decreased in the hypothyroid state (Maia et al. 1995c, Kim et al. 1998). In contrast, increased $\mathrm{D} 2$-catalyzed $\mathrm{T}_{4}$ to $\mathrm{T}_{3}$ conversion is anticipated due to the increase in the half-life of $\mathrm{D} 2$ protein and DIO2 transcription secondary to the decreased levels of free $\mathrm{T}_{4}\left(\mathrm{FT}_{4}\right)$ and $\mathrm{T}_{3}\left(\mathrm{FT}_{3}\right)$ respectively (Gereben et al. 2000, Bianco et al. 2005, Wagner et al. 2007). In the opposite direction, D1-catalyzed $\mathrm{T}_{3}$ production would predominate in the hyperthyroid state (see below). These assumptions are consistent with the predicted increased efficiency of D2-catalyzed $T_{4}$ to $T_{3}$ conversion as demonstrated in early studies; these studies showed that in hypothyroid patients, the fractional whole-body conversion rate of $\mathrm{T}_{4}$ to $\mathrm{T}_{3}$ was $42 \%$, whereas this rate fell to $21 \%$ in the same patients made euthyroid by $\mathrm{L} \mathrm{T}_{4}$ replacement therapy (Inada et al. 1975). Sustained elevations in serum $T_{3} / T_{4}$ ratios have also been reported in athyreotic subjects partially withdrawn from $T_{4}$ therapy (Lum et al. 1984).

In addition to the importance of the D1 and D2 in converting $\mathrm{T}_{4}$ to $\mathrm{T}_{3}$ in peripheral tissues, these enzymes are also highly expressed in the thyroid gland (Leonard \& Visser 1986, Toyoda et al. 1992, Schoenmakers et al. 1995, Salvatore et al. 1996, Leonard et al. 2001). D1 seems to be constitutively expressed in the human thyroid gland, whereas D2 expression varies closely with the degree of thyroid stimulation (Salvatore et al. 1996). The thyroidal contribution for overall thyroid hormone economy is estimated on two-thirds from hydrolysis of thyroglobulin and one-third from deiodination (Laurberg et al. 2007). Interestingly, perfusion studies demonstrated that dog and human thyroid have a preferential secretion of $\mathrm{T}_{3}$, favoring a more pronounced D1 activity in this gland (Laurberg 1978, Tegler et al. 1982).

The distinct subcellular localization of D1 and D2 might also contribute to its functional roles. D1 is located in the inner surface of the plasma membrane, whereas D2 is in the endoplasmic reticulum (Baqui et al. 2000), which could explain the early observations that $\mathrm{T}_{3}$ generated by $\mathrm{D} 1$ rapidly equilibrates with plasma $T_{3}$. Moreover, this deiodinase seems to be positioned much better to clear $\mathrm{rT}_{3}$ and other compounds from the circulation (Toyoda et al. 1997). The role of the facilitated deiodination of sulfated iodothyronines might be the recovery of the trace element iodine from inactive hormone metabolites, reutilized for $\mathrm{T}_{4}$ synthesis (Toyoda et al. 1997). On the other hand, D2-derived $T_{3}$ production has a greater effect on $\mathrm{T}_{3}$-dependent gene transcription than that from D1, which indicates that generation of nuclear $T_{3}$ is an intrinsic property of the D2 protein (Maia et al. 2005).

Important insights into the role of D1 for thyroid hormone metabolism were also obtained from two genetically modified animal models: $\mathrm{C} 3 \mathrm{H}$ strains, which present inherited low D1 expression in liver and kidney, and D1 KO mice, with targeted disruption of the Dio1 gene (Berry et al. 1993, Schoenmakers et al. 1993, Schneider et al. 2006). The reduced D1 activity in $\mathrm{C} 3 \mathrm{H}$ mice correlates with a CGT repeat insertion into the $5^{\prime}$-flanking region of the Dio1 gene that seems to impair C3H promoter potency (Maia et al. 1995a). Both the strains have elevated serum total and $\mathrm{FT}_{4}$ and $\mathrm{rT}_{3}$ but normal serum- $\mathrm{FT}_{3}$ and TSH concentrations. The normal $\mathrm{FT}_{3}$ concentration in these mice could be explained by the fact that, although the fractional conversion of $T_{4}$ to $T_{3}$ per day would be reduced, the higher $\mathrm{FT}_{4}$ concentration permits normal daily $\mathrm{T}_{3}$ production. In addition, serum $\mathrm{T}_{3}$ levels were significantly higher in $\mathrm{C} 3 \mathrm{H}$ than in $\mathrm{C} 57$ mice after the same dose of exogenous $T_{3}$, suggesting a reduction in $T_{3}$ clearance that might contribute to the maintenance of serum $\mathrm{T}_{3}$ concentrations (Maia et al. 1995c). However, the rate of disappearance of $\mathrm{T}_{3}$ was comparable in euthyroid WT and D1KO mice (Schneider et al. 2006). A potential source of serum $\mathrm{T}_{3}$ in both $\mathrm{C} 3 \mathrm{H}$ and $\mathrm{D} 1 \mathrm{KO}$ mice is $\mathrm{D} 2$-catalyzed $\mathrm{T}_{4}$ to $\mathrm{T}_{3}$ conversion. Indeed, it has been shown that, despite the higher serum- $\mathrm{FT}_{4}$, the levels of $\mathrm{D} 2$ activity in brown adipose tissue of $\mathrm{C} 3 \mathrm{H}$ mice are comparable to those observed in C57 animals (Wagner et al. 2007). The normal serum-FT 3 levels would lead to a euthyroid state in peripheral tissues and can account for the observed euthyroid phenotypes in both phenotypes. Of note, no cases of inherited D1 deficiency in human have been documented so far.

In the last decade, animal models with deficiency of both D1 and D2 enzymes were generated (Christoffolete et al. 2007, Galton et al. 2009). The C3H-D2KO mouse (targeted disruption of the Dio2 gene and genetically low D1 expression) has hepatic and renal D1 activities lower than those observed in wild-type mice (C57/BL6) but unexpectedly higher than those of the $\mathrm{C} 3 \mathrm{H}$ mice. These mice present euthyroid serum $\mathrm{T}_{3}$ levels and serum $\mathrm{T}_{4}$ levels even more augmented than in the $\mathrm{C} 3 \mathrm{H}$. The serum TSH is increased, which could be important to maintain euthyroid serum $\mathrm{T}_{3}$ concentrations. The double D1/D2KO mice are also able to maintain a normal serum $\mathrm{T}_{3}$ level and their general health, growth, and reproductive capacity are seemingly 
unimpaired (Galton et al. 2009). The authors underline the feature that D1 and D2 enzymes might not be essential to the maintenance of normal plasmatic $\mathrm{T}_{3}$ levels in the rodent as long as the hypothalamic-pituitary-thyroid axis is intact. These alterations, however, might not perfectly reflect those putatively found in humans, because the rat thyroid is responsible for $50 \%$ of the circulating $\mathrm{T}_{3}$, whereas humans depend more on peripheral deiodination, given that only $20 \%$ of the $\mathrm{T}_{3}$ is derived from the thyroid gland.

Iodine is essential for thyroid hormone synthesis, and iodine deficiency leads a series of physiological adaptations in the hypothalamic-pituitary-thyroid axis in an attempt to maintain plasma and tissue $\mathrm{T}_{3}$ in the normal range. The earliest thyroidal modification is a decrease in 3,5-diiodotyronine, with a consequent decrease in the thyroidal $\mathrm{T}_{4}$, whereas thyroidal $T_{3}$ remains constant (Riesco et al. 1976). Indeed, elevated plasma TSH, associated with decreased serum $\mathrm{T}_{4}$ and a virtually unchanged $T_{3}$, are the physiological hallmarks of moderate iodine deficiency as well as of the early phases of primary hypothyroidism. In both situations, however, the extrathyroidal changes are complex and involve a high degree of tissue specificity. It is observed that although D1 and D3 activity is unchanged in marginal iodine deficiency, D2 activity is markedly upregulated in D2-expressing tissues, thus increasing the proportion of $\mathrm{T}_{3}$ formed locally and mitigating the decreases in tissue $T_{3}$ content (Larsen et al. 1981, Janssen et al. 1994, Schröder-van der Elst et al. 1998). Interestingly, however, increase in liver D1 activity has been observed in severe iodine-deficient rats under selenium supplementation (Arthur et al. 1991). Of note, studies in the D1KO mouse demonstrated that iodothyronines other than $\mathrm{T}_{4}$ are the substrates for $5^{\prime}$-deiodination by D1 enzyme, which releases iodine back into the circulation (Schneider et al. 2006). In the absence of D1, inactive and lesser iodothyronines escape deiodination and are excreted in the feces with the potential loss of the associated iodine. This scavenging function of D1 might be particularly important in the iodine deficiency setting (Galton et al. 2009).

Recently, attention has been turned to a potential role of D1 in the biosynthesis of thyronamines (3-iodothyronamine, 3- $\mathrm{T}_{1} \mathrm{AM}$, and thyronamine, $\left.\mathrm{T}_{0} \mathrm{AM}\right)$, a newly identified class of endogenous compounds that seem to be isozyme-specific substrates of deiodinases (Scanlan et al. 2004, Piehl et al. 2008, Scanlan 2009). These molecules are chemical derivatives of thyronines, the principal chemical form of $\mathrm{T}_{4}$ that appears to antagonize the typical actions of thyroid hormones. It has been shown that the iodothyronamines have $V_{\max } / K_{\mathrm{m}}$ values comparable to the corresponding iodothyronine, indicating that they would be as readily deiodinated as iodothyronines by the appropriate deiodinase isoenzyme (Piehl et al. 2008). Nevertheless, unlike $\mathrm{T}_{4}, \mathrm{~T}_{4} \mathrm{AM}$ is not a substrate for D1 or $\mathrm{D} 2$ enzymes. Instead, $\mathrm{T}_{4} \mathrm{AM}$ is readily deiodinated to $3,3^{\prime}, 5^{\prime}-$ triiodothyronamide $\left(\mathrm{rT}_{3} \mathrm{AM}\right)$ by $\mathrm{D} 3$, and $\mathrm{rT}_{3} \mathrm{AM}$ can be further deiodinated to ultimately provide $\mathrm{T}_{1} \mathrm{AM}$. Using HepG2 cell lysates or mouse liver membrane fractions, D1 was able to use $\mathrm{rT}_{3} \mathrm{AM}$ or $3^{\prime}, 5^{\prime}$-diiodothyronamine $\left(3^{\prime}, 5^{\prime}-\mathrm{T}_{2} \mathrm{AM}\right)$ as substrates and both reactions were sensitive to PTU. On the other hand, $\mathrm{T}_{1} \mathrm{AM}$ is the most efficiently processed thyronamine substrate using a sulfotransferase preparation from human liver, and the $V_{\max } / \mathrm{KM}$ value for $\mathrm{T}_{1} \mathrm{AM}$ compares to that of $\mathrm{T}_{3}$, suggesting that similar to $\mathrm{T}_{3}$, sulfation of $\mathrm{T}_{1} \mathrm{AM}$ may be an important clearance mechanism for regulating free circulating levels (Piehl et al. 2008). The physiological role of thyronamines is uncertain, but pharmacological data show that a single-dose $\mathrm{T}_{1} \mathrm{AM}$ administration in vivo induces intense hypothermia and bradycardia, leading to a hypometabolic state that may confer a potential neuroprotective benefit in cases of ischemic injury (Scanlan et al. 2004). Indeed, $\mathrm{T}_{1} \mathrm{AM}$ treatment was found to reduce infarct volume by $40 \%$ in a middle cerebral artery occlusion stroke model in mice. Interestingly, the degree of neuroprotection afforded by $\mathrm{T}_{1} \mathrm{AM}$ was correlated with the magnitude of $\mathrm{T}_{1} \mathrm{AM}$-induced hypothermia (Doyle et al. 2007). These findings indicate the existence of an exciting signaling pathway that leads to rapid physiological effects that are opposite to those produced by thyroid hormone excess (Scanlan 2009). Nevertheless, as pointed out by the authors, the precise relationship between $\mathrm{T}_{1} \mathrm{AM}$ and thyroid hormone remains poorly understood, and there is currently no direct evidence for in vivo thyroid hormone-derived synthesis of thyronamines.

\section{Role of type 1 deiodinase in human disease}

\section{DIO1 polymorphisms}

As stated above, no cases of inherited D1 deficiency have been reported so far and, remarkably, no mutations have been identified in any of the deiodinase enzyme-encoding genes to date. In contrast, however, several genetic variations have been described in DIO1 and DIO2 genes, which may influence circulating or intracellular thyroid hormone levels (Peeters et al. 2006, Butler et al. 2010, Dora et al. 2010).

Two SNPs in the human DIO1 gene, D1a-C/T (variation at the nucleotide position 785 of the D1 cDNA sequence $\mathrm{C} 785 \mathrm{~T}$ ) and $\mathrm{D} 1 \mathrm{~b}-\mathrm{A} / \mathrm{G}$ (variation at the position 1814 A1814G), have been associated with changes in serum $\mathrm{rT}_{3}$ levels (Peeters et al. 2003a). Each T-allele of D1a-T (frequency of $34 \%$ ) was associated with an increase of $\sim 2 \mathrm{ng} / \mathrm{dl}$ in plasma $\mathrm{rT}_{3}$ levels, whereas the less frequent $\mathrm{G}$ allele of $\mathrm{D} 1 \mathrm{~b}(10 \cdot 3 \%)$ was associated with lower $\mathrm{rT}_{3} / \mathrm{T}_{4}$ and higher $\mathrm{T}_{3} / \mathrm{rT}_{3}$ plasma ratios. In the elderly, carriers of the $D 1 a-T$ allele had higher serum- $\mathrm{FT}_{4}$ and $\mathrm{rT}_{3}$, lower $\mathrm{T}_{3}$, and lower $\mathrm{T}_{3} / \mathrm{rT}_{3}$, whereas the $D 1 b-G$ allele was associated with higher serum $\mathrm{T}_{3}$ and $\mathrm{T}_{3} / \mathrm{rT}_{3}$ (de Jong et al. 2007). Consistently with a lower D1 activity for the DIO1-785T, a recent study has shown that the administration of $T_{3}$ to individuals harboring this variant was associated with enhanced potentiation of the effect of the antidepressant sertraline (Cooper-Kazaz et al. 2009). The genetic influence of these polymorphisms in healthy Danish twins has also been addressed and revealed that carriers of the DIO1-785T allele had 3.8\% higher $\mathrm{FT}_{4}$ and $14 \cdot 3 \%$ higher $\mathrm{rT}_{3}$ 
levels, resulting in a lower $\mathrm{T}_{3} / \mathrm{T}_{4}$ and $\mathrm{T}_{3} / \mathrm{rT}_{3}$ ratio and a higher $\mathrm{rT}_{3} / \mathrm{T}_{4}$ ratio. The $\mathrm{D} 1 \mathrm{~b}-\mathrm{A} / \mathrm{G}$ polymorphism, however, was not associated with changes in serum thyroid hormone levels (van der Deure et al. 2009). As both SNPs are located in the 3'-UTR, it has been speculated whether the mRNA stability would be compromised or affect mRNA folding, which is necessary for the incorporation of Sec in the catalytic center of the protein (Peeters et al. 2003a).

The D1a-C/T and D1b-A/G polymorphisms have also been associated with changes in free insulin-like growth factor 1 (IGF1) levels (Peeters et al. 2005a). Based on the data derived from the four haplotype alleles and corresponding serum thyroid hormone levels in two different populations, the authors assumed that the haplotype D1a-T/D1bA is associated with decreased D1 activity, whereas patients with the haplotype D1a-C/D1bG displays increased D1 levels. The D1a-T/D1bA haplotype was associated with higher levels of free IGF1 levels, which could serve as a tentative mechanism for normalization of D1 activity. Of note, this haplotype showed an allele dose effect on serum $\mathrm{T}_{3}$ concentrations in elderly men (resulting in lower levels of $\mathrm{T}_{3}$ ) but not in the population constituted by healthy blood donors.

Recently, a new polymorphism A/C located in intron 3 of the human DIO1 gene has been described (Panicker et al. 2008). This polymorphism was associated with increased $\mathrm{FT}_{3}$ and decreased $\mathrm{FT}_{4}$ and $\mathrm{rT}_{3}$ levels not only in patients receiving thyroid hormone replacement therapy but also in a large group of healthy individuals. Of interest, in both the groups, the former described that $\mathrm{D} 1 \mathrm{a}-\mathrm{C} / \mathrm{T}$ SNP also leads to variations in $\mathrm{T}_{3}, \mathrm{FT}_{4}$, and $\mathrm{rT}_{3}$ levels, although in a less pronounced fashion (Peeters et al. 2003a, de Jong et al. 2007, Panicker et al. 2008). The effect of the A/C polymorphism is consistent with the $C$-allele being associated with higher D1 enzymatic activity. Although the mechanism by which this polymorphism affects deiodinase function remains unknown, the authors estimate that it accounts for nearly $2 \%$ of genetic variance of $\mathrm{FT}_{4}$ and $1 \cdot 5 \%$ of $\mathrm{FT}_{3}$.

\section{Graves's hyperthyroidism and multinodular goiter}

It is well established that hyperthyroid patients suffering from Graves' disease or multinodular toxic goiter have a disproportionate increase of serum $\mathrm{T}_{3}$ as compared with the increase in serum $\mathrm{T}_{4}$ (Larsen 1972, Nicoloff et al. 1972, Woeber 2006). In both diseases, thyroid hormone production is no longer targeted to physiological needs; instead, it is driven by a number of abnormalities. In Graves' disease, the abnormal generation of stimulating antibodies of TSH receptor is implicated (Davies et al. 2005, Laurberg et al. 2008), whereas in multinodular goiter, a constitutive activation of the thyroid follicular cells occurs (Krohn et al. 2005).

Thyroid hormone excess could be a result of either increased thyroidal $T_{3}$ production or elevated quantities of $\mathrm{T}_{3}$ from peripheral $\mathrm{T}_{4}$ to $\mathrm{T}_{3}$ conversion. This central question was recently addressed by Laurberg et al. (2007) in untreated patients with Graves' disease or multinodular goiter. In agreement with earlier studies (Abuid \& Larsen 1974), it was observed that patients treated only with PTU, a specific inhibitor of D1, presented a rapid and sustained fall in serum $\mathrm{T}_{3}$ levels of $\sim 57 \%$, whereas those treated with a combination of PTU plus potassium iodine or sodium ipodate, which inhibits both D1 and D2 and several processes involved in thyroid hormone production and secretion respectively, present an additional fall of $\sim 20 \%$. Considering that the secretion of intrathyroidal and peripheral $\mathrm{T}_{3}$ is selectively inhibited by PTU, the authors demonstrated that $\mathrm{D} 1$ deiodination has a crucial role in $\mathrm{T}_{3}$ generation in these diseases. In fact, although thyroidal D1 contributes $6 \%$ of daily thyroidal normal $\mathrm{T}_{3}$ production, this can increase to around $57 \%$ in patients with severe hyperthyroidism, suggesting that the major source of serum $\mathrm{T}_{3}$ in hyperthyroid patients is the thyroid gland as a consequence of increased thyroidal D1 (Fig. 2). The remainder of the thyroidal $\mathrm{T}_{3}$ production is derived from thyroglobulin, with a nearly doubled $\mathrm{T}_{3}$ to $\mathrm{T}_{4}$ ratio, plus fractional $T_{4}$ to $T_{3}$ conversion in the peripheral tissues. As

\section{Euthyroidism}

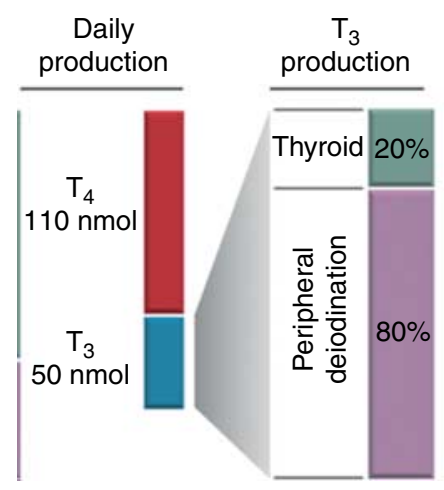

Figure 2 Schematic representation

the estimated sources of $\mathrm{T}_{3}$ production in euthyroid and hyperthyroid state. total $\mathrm{T}_{3}$ production in severe hyperthyroidism (derived from Laurberg et al. 2007).
Hyperthyroidism

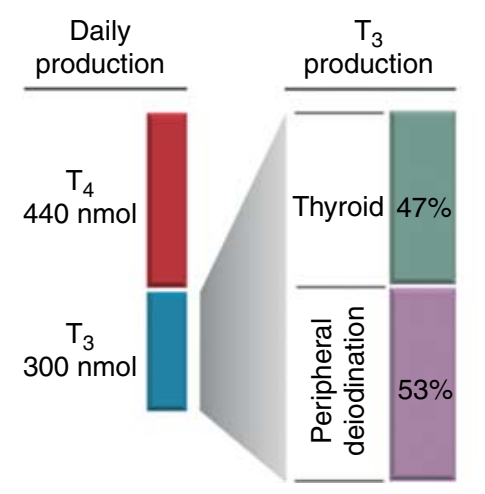

Severe hyperthyroidism

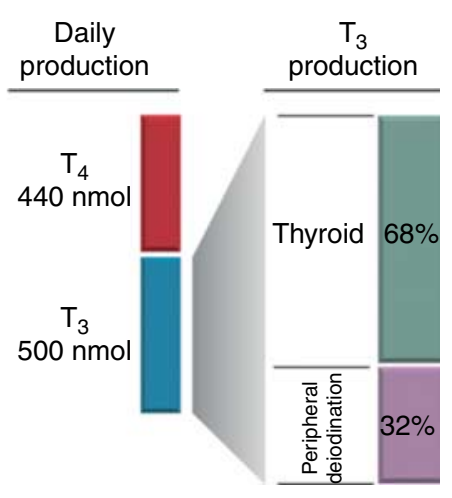


liver and kidney D1 increases in the presence of excessive thyroid hormone levels, this enzyme is also responsible for the majority of the peripheral $\mathrm{T}_{3}$ production (Maia et al. 2005, Laurberg et al. 2007). These observations support the choice of PTU as the preferred thionamide for therapy in severe hyperthyroidism or thyroid storm (Maia 2007). Nevertheless, methimazole is superior to PTU during chronic therapy (Nakamura et al. 2007). The reasons are the longer duration of methimazole action that favors better compliance and improves prognosis and the lower frequency of side effects compared with PTU. Moreover, the relatively low doses of PTU used in chronic therapy will not effectively inhibit D1.

The high thyroidal $T_{3}$ production might explain the pattern of persistently high serum $\mathrm{T}_{3}$ with normal or low serum $\mathrm{T}_{4}$ levels during treatment observed in a minority of patients with $\mathrm{T}_{3}$-predominant Graves' disease. Recently, D1 and D2 activities were evaluated in samples of thyroid tissue from patients with $\mathrm{T}_{3}$-predominant Graves' disease pretreated with methimazole before thyroidectomy (Ito et al. 2011). Intriguingly, not only an augmented activity of both enzymes but also a correlation between the thyroidal D2 activity and serum $\mathrm{FT}_{3}$ to $\mathrm{FT}_{4}$ ratio was observed, even more robust than that of thyroidal D1 activity.

\section{Fasting and nonthyroidal illness syndrome}

Fasting and severe illness induce profound changes in the thyroid hormone economy marked by decreases in serum $\mathrm{T}_{3}$ and $\mathrm{T}_{4}$ levels without a compensatory rise in the serum TSH level in both animal models and humans (Leonard et al. 1991, Nishikawa et al. 1998). Indeed, the decrease in the concentration of circulating $T_{3}$ relative to that of $T_{4}$ and an increase in $\mathrm{rT}_{3}$ concentrations in fasting humans was one of the earliest indications that the peripheral metabolism of thyroid hormones could be modulated by physiological or physiopathological events (Portnay et al. 1974). Nevertheless, the complex physiopathological mechanisms responsible for these systemic changes remain poorly understood (Warner \& Beckett 2010). Changes in deiodinases expression have been postulated to play important roles in the altered circulating levels of thyroid hormones in fasting and nonthyroidal illness syndrome (NTIS) (Debaveye et al. 2008, Kwakkel et al. 2009). Decrease in $T_{3}$ production could be explained by decreased levels of D1 and/or D2, whereas the elevation of $\mathrm{rT}_{3}$ could be due to decreased activity of D1 and the increase in D3 activity, which determines increased hormone degradation (Peeters et al. 2003b, 2005b).

In rodents, fasting induces decrease in liver and pituitary D1 activities. However, it is not established whether this reduction is due to a direct effect of fasting on D1 activity or secondary to the decreased levels of serum thyroid hormones, which is also observed in this situation (St Germain \& Galton 1985, O’Mara et al. 1993, Aceves et al. 2003). Interestingly, it has been demonstrated that leptin, an adipocyte-derived hormone that is diminished in food deprivation, modulates the $5^{\prime}$-deiodinases in different tissues depending on the energetic status (Cabanelas et al. 2006). Leptin was shown to exert direct peripheral effects on deiodinase activity, positively regulating liver, kidney, and pituitary D1 activity in fed animals (Cabanelas et al. 2006).

Results with leptin replacement in fasting, however, have produced contradictory results depending on the tissue analyzed. Some studies failed to demonstrate a decrease in hepatic D1 activity on food-restricted animals in rats treated with i.c.v. leptin injection (Ahima et al. 1996, Legradi et al. 1997, Cusin et al. 2000), whereas others showed that the decrease in thyroid D1 is not restored by leptin replacement. In the latter, the authors suggest that the diminished D1 activity could result from the increased levels of corticosterone observed in these animals (Araujo et al. 2009). Conversely, rats with high-fatinduced obesity presented increased D1 activity in the thyroid, liver, and kidney and higher rates of oxygen consumption and energy expenditure, without changes in the thyroid hormone circulating levels (Araujo et al. 2010). In starved humans, circulating $\mathrm{T}_{3}$ concentrations decrease rapidly to about $50 \%$ of control and remain low for up to 3 weeks of fasting (Vignati et al. 1978, Kaptein et al. 1985, Rosenbaum et al. 2005). However, the sustained decrease in serum $\mathrm{T}_{4}$ and $\mathrm{T}_{3}$ could also be due to increased thyroid hormone inactivation by D3 enzyme, as recently reported in other pathological situations (Olivares et al. 2007, Simonides et al. 2008).

An entire set of data obtained from critically ill patients demonstrated that patients with more pronounced alterations in serum thyroid parameters have a significantly higher mortality rate and that $\mathrm{rT}_{3}$ and $\mathrm{T}_{3} / \mathrm{rT}_{3}$ are prognostic factors for survival (Peeters et al. 2005c). Critically ill patients showed reduced hepatic D1 activity, which was negatively correlated with $\mathrm{T}_{3}$ and $\mathrm{rT}_{3}$ plasma levels. Interestingly, D1 activity in liver was lowest in patients who died of cardiovascular collapse and highest in patients who died of brain damage. Lower D1 activity was also observed in patients with acute renal failure and in those receiving inotropes, compared with those who did not require these treatments (Peeters et al. 2003b). In contrast, other studies found no differences in D1 activity measured in the subcutaneous adipose tissue in patients in intensive care units, suggesting that thyroid hormone bioavailability might be regulated in a tissue-specific way (Rodriguez-Perez et al. 2008).

Cytokines, such as IL1, IL6, TNF $\alpha$, have been postulated as potential mediators of the alterations in thyroid function that occur during severe illness (Chopra et al. 1991, Boelen et al. 1993, Pekary et al. 1994). Studies in health volunteers demonstrated that a single dose of IL6 caused a transient decrease in serum $\mathrm{T}_{3}$ and TSH (Torpy et al. 1998), changes that are characteristic of the NTIS. In hospitalized patients, there is also an inverse correlation between the serum IL6 and the $\mathrm{T}_{3}$ concentrations (Boelen et al. 1993, 1995, Davies et al. 1996a). These proinflammatory molecules seem to inhibit the expression and function of D1 in human hepatocarcinoma 
cells (HepG2; Jakobs et al. 2002), whereas studies on rat hepatocytes have demonstrated that IL1 and IL6 impair the $\mathrm{T}_{3}$ induction of $\mathrm{D} 1 \mathrm{mRNA}$ by a mechanism that involves a functional disruption of steroid receptor coactivator 1 (SRC-1)-thyroid hormone receptor interaction caused by competition between IL1 and $\mathrm{T}_{3}$-stimulated transcriptional events for limiting quantities of SRC-1 (Yu \& Koenig 2000, Jakobs et al. 2002). The $\mathrm{T}_{3}$ inhibitory effect of IL1 $\beta$ was salvaged by coexpression of the nuclear SRC-1 but not by cAMP response element binding protein ( $\mathrm{Yu}$ \& Koenig 2006).

The effects of TNF $\alpha$ have been examined in hepatocytes and HepG2 cells with contradictory results. TNF $\alpha$ decreased the $\mathrm{T}_{3}$-stimulated D1 mRNA in HepG2 cells (Nagaya et al. 2000). In a second study in dispersed rat hepatocytes, IL1 $\beta$ and IL6 blocked the $\mathrm{T}_{3}$ induction of D1 mRNA and activity but TNF $\alpha$ had no effect on D1 expression (Yu \& Koenig 2000). The contradictory effects observed could be due to differences in the experimental paradigms. Despite this, both studies suggest that a mechanism for acute decrease in D1 expression during illness could be competition for limited amounts of one or more transcription factors that are rate limiting for both cytokine- and $\mathrm{T}_{3}$-dependent transcriptional events. In has been shown in in vitro studies that IL1 $\beta$ stimulates both D1 and D2 expression (Baur et al. 2000).

\section{Human neoplasias}

The balance between proliferation and differentiation is among the wide variety of biological events influenced by thyroid hormone and recent studies suggest that deiodinase enzymes might play an important role in the control of thyroid hormone metabolism and action during tumorigenesis. Studies focusing on DIO1 and DIO2 gene expression in benign and malignant thyroid tumors have demonstrated that D1 and D2 expression are diminished, whereas D3 is increased in tumoral tissue (Arnaldi et al. 2005, Meyer et al. 2007, Dentice et al. 2009).

Changes in D1 expression have been proposed as a marker of the epithelial follicular thyroid cell dedifferentiation (Schreck et al. 1994, Kohrle 1997, Meyer et al. 2007). Significant decreases in D1 mRNA and activity levels were demonstrated in samples of papillary thyroid carcinoma (PTC) as compared with adjacent normal thyroid tissues (de Souza Meyer et al. 2005). These results were observed in all histological subtypes, especially in the classical form of PTC, as well as in the different clinical stages (Ambroziak et al. 2005, Arnaldi et al. 2005, de Souza Meyer et al. 2005). In contrast to PTC samples, D1 levels were normal or increased in follicular thyroid adenoma, follicular thyroid carcinoma (FTC), and Hürthle cells carcinoma (Arnaldi et al. 2005, de Souza Meyer et al. 2005). These findings illustrate the distinct D1 expression patterns in PTC and follicular neoplasias, thus suggesting that downregulation of D1 expression is an early event in thyroid cell dedifferentiation toward PTC.
Although earlier studies reported that D1 activity was absent in samples of anaplastic thyroid carcinoma (ATC; Schreck et al. 1994), more recent studies reported high levels of $D 1 \mathrm{mRNA}$ and activity in sample of a mixed anaplastic and Hürthle cell carcinoma (de Souza Meyer et al. 2005). Undifferentiated thyroid carcinomas are the end-stage forms of thyroid cancer and are believed to arise from papillary or follicular carcinomas. Based on the above observation, one could speculate that the lack of expression of this isoenzyme could be a marker of papillary origin.

Changes on D1 regulation were also documented in various thyroid cancer cells. Using cell lines of FTC (FTC133 and FTC-238), Schreck et al. (1994) have demonstrated that D1 loses its responsiveness to TSH and $\mathrm{T}_{3}$ stimuli, but not to RA, a component that regulates growth rates and differentiation of several cell types. Low basal D1 activity, which is markedly increased by RA, was described in these cell lines but neither basal nor RA-inducible D1 activity is detected in cell lines derived from ATC (HTh 74 and C 643) (Schreck et al. 1994, Schmutzler et al. 2004). Proliferations of FTC-133 and FTC-238 cells were decreased by all-trans RA. Pretreatment of FTC-133 with RA resulted in a reduced tumor growth in xenotransplantation experiments as compared with untreated control cells (Schmutzler et al. 2004). These studies indicate that the coexpression of D1 and RA receptors in differentiated thyroid carcinoma preserves its basal regulatory functions in contrast to less differentiated thyroid neoplasias.

Downregulation of D1 expression was also reported in other human neoplasias. Lower levels of D1 mRNA were described in samples of renal clear cell carcinoma, the most frequent renal cancer (Pachucki et al. 2001). Interestingly, several variants of DIO1 transcripts were found in this type of neoplasias, all of them underexpressed in tumor tissue as compared with normal renal tissue. These findings suggest a possible role of disturbed expression of splicing factors splicing factor-2/alternative splicing factor (SF2/ASF) and heterogeneous ribonucleoprotein A1 (hnRNPA1) in samples of human renal cancer (Piekielko-Witkowska et al. 2009). Low levels of D1 expression were also demonstrated in liver carcinoma when compared with normal tissue (Sabatino et al. 2000). In addition, HepG2 cells exhibit high levels of D1 activity, which is stimulated by RA or $\mathrm{T}_{3}$ (Schreck et al. 1994, Toyoda et al. 1995). Hemangioma tissue presents nearly undetectable D1 activity compared with healthy liver tissue (Kornasiewicz et al. 2010). In addition, decreased D1 activity was described in pulmonary squamous cell cancer, adenocarcinoma (Wawrzynska et al. 2003), and prostate cancer (Dutkiewicz et al. 1995).

On other hand, mammary cancer induced in SpragueDawley mice with $\mathrm{N}$-methyl- $\mathrm{N}$-nitrourea had twice as much D1 activity when compared with normal, nonlactating tissue (Macejova et al. 2001). Interestingly, D1 levels were higher in 2to 4-month-old tumors when compared with 6-month-old tumors (Macejova et al. 2001), characterizing a loss of D1 expression with tumor progression. Besides, the MCF-7 cells 
(an ovarian hormone-dependent cell line derived from mammary cancer) also present D1 regulated by RA, although it does not respond to $\mathrm{T}_{3}$ or isoproterenol (Garcia-Solis \& Aceves 2003). Similar to that observed in other cells lines, no detectable activity of D1 is present in less differentiated mammary cell lines (MDA-MB-231), either in basal conditions or under different treatments (Garcia-Solis \& Aceves 2003). Human breast cancer tissue expresses high levels of D1 activity and mRNA, a profile unlike most other human tumors of epithelial origin (Debski et al. 2007).

D1 activity is found in normal pituitary as well as human pituitary adenomas. Although a wide variation on D1 activity among the tumor histological subtypes has been reported, the highest activities were seen in the thyrotroph and lactotroph adenomas. Approximately, half of these tumors presented D1 activities several-fold greater than any of the normal pituitary samples (Baur et al. 2002, Tannahill et al. 2002).

In summary, except for the follicular thyroid lesions and tumors originating in the mammary gland, D1 expression is decreased in the majority of human neoplasias of epithelial origin. Nevertheless, whether it is part or consequence of the neoplastic process still remains to be clarified. A possible explanation for the decreased D1 expression could be loss of physiological response to $\mathrm{T}_{3}$ due to aberrant expression of TRs or a high frequency of TR mutations, as reported in several human tumors (Cheng et al. 2010). One can also speculate that it is a result of the low intracellular $\mathrm{T}_{3}$ level secondary to D3 overexpression (Dentice et al. 2009). Nevertheless, because tumor tissue may represent a more homogeneous population of cells than normal tissue, we cannot rule out that changes in expression could also be secondary to a difference in the cell types, rather than a change in expression level in cancer cell itself.

\section{Conclusion}

Since the identification, several decades ago, of the type 1 deiodinase, a considerable amount of research has been carried out in an attempt to extend our knowledge of its molecular and biochemical properties as well as our understanding of its role in human thyroid hormone metabolism. This enzyme is a member of a family of oxidoreductases that contains the rare amino acid $\mathrm{Sec}$ in its active site and D1-catalyzed reaction follows ping-pong kinetics with two substrates: the first being the iodothyronine and the second being an endogenous intracellular thiol cofactor. Besides its capacity of outer-ring deiodination, which contributes to daily $\mathrm{T}_{3}$ production, $\mathrm{D} 1$ also catalyzes the iodine removal by inner-ring deiodination inactivating thyroid hormones. Indeed, the remarkable D1 preference for $\mathrm{rT}_{3}$ as the enzymatic outer-ring deiodination substrate as well as the deiodination of sulfated iodothyronines argues for a major scavenging function of this enzyme, namely the recovery of the trace element iodine from inactive hormone metabolites to be reutilized for thyroid hormone synthesis.
This functional role can be particularly relevant in a setting of iodine deficiency.

A multiplicity of hormonal, nutritional, and developmental factors modulates D1 expression. Thyroid hormone is the most important physiological upregulator of D1 expression, and hypothyroidism is associated with low levels of D1 mRNA and activity. D1 activity is also susceptible to selenium deficiency, and selenium-deficient individuals have mildly elevated serum $\mathrm{T}_{4}$ and $\mathrm{T}_{4}$ to $\mathrm{T}_{3}$ ratios, but normal TSH.

Besides its role in human physiological control of peripheral thyroid hormone metabolism, alterations in D1 expression and activity have also been described in human diseases. Polymorphisms in DIO1 gene have been associated with changes on thyroid hormone levels, whereas augmented thyroidal D1-catalyzed $\mathrm{T}_{3}$ generation seems to play a major role in $T_{3}$ overproduction observed in Graves' disease and multinodular goiter. Decreased D1 expression has been implicated in the thyroid hormone changes observed in fasting and NTIS, whereas disturbed expression and regulation of this enzyme is reported in human neoplasias.

Nonetheless, there are still significant gaps in our knowledge of D1 function in human physiology. The endogenous cofactor is as yet unidentified, which may jeopardize conclusions obtained from in vitro studies using artificial conditions. The relative role of peripheral D1-catalyzed $\mathrm{T}_{3}$ production in human euthyroid state or in pathological processes, such as NTIS, is still a matter of debate. D1 expression is decreased in the majority of human tumors of epithelial origin but whether this occurs as an attempt to counter-regulate the proliferate state or contribute to the dedifferentiation process to the neoplasm remains to be determined. Further studies in the exciting field of thyroid hormone metabolism are warranted to unravel these unanswered questions.

\section{Declaration of interest}

The authors declare that there is no conflict of interest that could be perceived as prejudicing the impartiality of the research reported.

\section{Funding}

This work was supported by Coordenação de Aperfeiçoamento de Pessoal de Nível Superior (CAPES), Conselho Nacional de Desenvolvimento Científico e Tecnológico (CNPq), Fundação de Apoio a Pesquisa do Rio Grande do Sul (FAPERGS), and Fundação de Incentivo a Pesquisa (FIPE), Brazil.

\section{References}

Abuid J \& Larsen PR 1974 Triiodothyronine and thyroxine in hyperthyroidism. Comparison of the acute changes during therapy with antithyroid agents. Journal of Clinical Investigation 54 201-208. (doi:10.1172/JCI107744)

Aceves C, Escobar C, Rojas-Huidobro R, Vazquez-Martinez O, MartinezMerlos T, Aguilar-Roblero R \& Diaz-Munoz M 2003 Liver 5'-deiodinase 
activity is modified in rats under restricted feeding schedules: evidence for post-translational regulation. Journal of Endocrinology 179 91-96. (doi:10. 1677/joe.0.1790091)

Ahima RS, Prabakaran D, Mantzoros C, Qu D, Lowell B, Maratos-Flier E \& Flier JS 1996 Role of leptin in the neuroendocrine response to fasting. Nature 382 250-252. (doi:10.1038/382250a0)

Alcantara MR, Salvatori R, Alcantara PR, Nobrega LM, Campos VS, Oliveira EC, Oliveira MH, Souza AH \& Aguiar-Oliveira MH 2006 Thyroid morphology and function in adults with untreated isolated growth hormone deficiency. Journal of Clinical Endocrinology and Metabolism 91 860-864. (doi:10.1210/jc.2005-2555)

Ambroziak M, Pachucki J, Stachlewska-Nasfeter E, Nauman J \& Nauman A 2005 Disturbed expression of type 1 and type 2 iodothyronine deiodinase as well as titf1/nkx2-1 and pax- 8 transcription factor genes in papillary thyroid cancer. Thyroid 15 1137-1146. (doi:10.1089/thy.2005.15.1137)

Araujo RL, Andrade BM, da Silva ML, Ferreira AC \& Carvalho DP 2009 Tissuespecific deiodinase regulation during food restriction and low replacement dose of leptin in rats. American Journal of Physiology. Endocrinology and Metabolism 296 E1157-E1163. (doi:10.1152/ajpendo.90869.2008)

Araujo RL, Andrade BM, Padron AS, Gaidhu MP, Perry RL, Carvalho DP \& Ceddia RB 2010 High-fat diet increases thyrotropin and oxygen consumption without altering circulating $3,5,3^{\prime}$-triiodothyronine $\left(\mathrm{T}_{3}\right)$ and thyroxine in rats: the role of iodothyronine deiodinases, reverse $T_{3}$ production, and whole-body fat oxidation. Endocrinology 151 3460-3469. (doi:10.1210/en.2010-0026)

Arnaldi LA, Borra RC, Maciel RM \& Cerutti JM 2005 Gene expression profiles reveal that DCN, DIO1, and DIO2 are underexpressed in benign and malignant thyroid tumors. Thyroid 15 210-221. (doi:10.1089/thy.2005. 15.210)

Arthur JR, Nicol F, Grant E \& Beckett GJ 1991 The effects of selenium deficiency on hepatic type-I iodothyronine deiodinase and protein disulphide-isomerase assessed by activity measurements and affinity labelling. Biochemical Journal 15 297-300.

Baqui MM, Gereben B, Harney JW, Larsen PR \& Bianco AC 2000 Distinct subcellular localization of transiently expressed types 1 and 2 iodothyronine deiodinases as determined by immunofluorescence confocal microscopy. Endocrinology 141 4309-4312. (doi:10.1210/en.141.11.4309)

Bates JM, St Germain DL \& Galton VA 1999 Expression profiles of the three iodothyronine deiodinases, D1, D2 and D3, in the developing rat. Endocrinology 140 844-851. (doi:10.1210/en.140.2.844)

Bates JM, Spate VL, Morris JS, St Germain DL \& Galton VA 2000 Effects of selenium deficiency on tissue selenium content, deiodinase activity, and thyroid hormone economy in the rat during development. Endocrinology 141 2490-2500. (doi:10.1210/en.141.7.2490)

Baur A, Bauer K, Jarry H \& Kohrle J 2000 Effects of proinflammatory cytokines on anterior pituitary $5^{\prime}$-deiodinase type I and type II. Journal of Endocrinology 167 505-515. (doi:10.1677/joe.0.1670505)

Baur A, Buchfelder M \& Kohrle J 2002 Expression of 5'-deiodinase enzymes in normal pituitaries and in various human pituitary adenomas. European Journal of Endocrinology 147 263-268. (doi:10.1530/eje.0.1470263)

Beckett GJ, Beddows SE, Morrice PC, Nicol F \& Arthur JR 1987 Inhibition of hepatic deiodination of thyroxine is caused by selenium deficiency in rats. Biochemical Journal 248 443-447.

Beech SG, Walker SW, Arthur JR, Lee D \& Beckett GJ 1995 Differential control of type-I iodothyronine deiodinase expression by the activation of the cyclic AMP and phosphoinositol signalling pathways in cultured human thyrocytes. Journal of Molecular Endocrinology 14 171-177. (doi:10.1677/jme. $0.0140171)$

Bermano G, Nicol F, Dyer JA, Sunde RA, Beckett GJ, Arthur JR \& Hesketh JE 1995 Tissue-specific regulation of selenoenzyme gene expression during selenium deficiency in rats. Biochemical Journal 311 425-430.

Berry MJ, Kates AL \& Larsen PR 1990 Thyroid hormone regulates type I deiodinase messenger RNA in rat liver. Molecular Endocrinology 4 743-748. (doi:10.1210/mend-4-5-743)

Berry MJ, Banu L \& Larsen PR 1991a Type I iodothyronine deiodinase is a selenocysteine-containing enzyme. Nature 349 438-440. (doi:10.1038/ 349438a0)
Berry MJ, Banu L, Chen YY, Mandel SJ, Kieffer JD, Harney JW \& Larsen PR $1991 b$ Recognition of UGA as a selenocysteine codon in type I deiodinase requires sequences in the $3^{\prime}$ untranslated region. Nature 353 273-276. (doi:10.1038/353273a0)

Berry MJ, Kieffer JD, Harney JW \& Larsen PR 1991c Selenocysteine confers the biochemical properties characteristic of the type I iodothyronine deiodinase. Journal of Biological Chemistry 266 14155-14158.

Berry MJ, Grieco D, Taylor BA, Maia AL, Kieffer JD, Beamer W, Glover E, Poland A \& Larsen PR 1993 Physiological and genetic analyses of inbred mouse strains with a type I iodothyronine $5^{\prime}$ deiodinase deficiency. Journal of Clinical Investigation 92 1517-1528. (doi:10.1172/JCI116730)

Bianco AC, Maia AL, da Silva WS \& Christoffolete MA 2005 Adaptive activation of thyroid hormone and energy expenditure. Bioscience Reports 25 191-208. (doi:10.1007/s10540-005-2885-6)

Boelen A, Platvoet-Ter Schiphorst MC \& Wiersinga WM 1993 Association between serum interleukin-6 and serum 3,5, $3^{\prime}$-triiodothyronine in nonthyroidal illness. Journal of Clinical Endocrinology and Metabolism 77 1695-1699. (doi:10.1210/jc.77.6.1695)

Boelen A, Platvoet-Ter Schiphorst MC \& Wiersinga WM 1995 Soluble cytokine receptors and the low 3,5,3'-triiodothyronine syndrome in patients with nonthyroidal disease. Journal of Clinical Endocrinology and Metabolism 80 971-976. (doi:10.1210/jc.80.3.971)

Butler PW, Smith SM, Linderman JD, Brychta RJ, Alberobello AT, Dubaz OM, Luzon JA, Skarulis MC, Cochran CS, Wesley RA et al. 2010 The Thr92Ala $5^{\prime}$ type 2 deiodinase gene polymorphism is associated with a delayed triiodothyronine secretion in response to the thyrotropinreleasing hormone-stimulation test: a pharmacogenomic study. Thyroid 20 1407-1412. (doi:10.1089/thy.2010.0244)

Cabanelas A, Lisboa PC, Moura EG \& Pazos-Moura CC 2006 Leptin acute modulation of the $5^{\prime}$-deiodinase activities in hypothalamus, pituitary and brown adipose tissue of fed rats. Hormone and Metabolic Research 38 481-485. (doi:10.1055/s-2006-949527)

Callebaut I, Curcio-Morelli C, Mornon JP, Gereben B, Buettner C, Huang S, Castro B, Fonseca TL, Harney JW, Larsen PR et al. 2003 The iodothyronine selenodeiodinases are thioredoxin-fold family proteins containing a glycoside hydrolase clan GH-A-like structure. Journal of Biological Chemistry 278 36887-36896. (doi:10.1074/jbc.M305725200)

Calomme M, Vanderpas J, Francois B, Van Caillie-Bertrand M, Vanovervelt N, Van Hoorebeke C \& Vanden Berghe D 1995 Effects of selenium supplementation on thyroid hormone metabolism in phenylketonuria subjects on a phenylalanine restricted diet. Biological Trace Element Research $\mathbf{4 7}$ 349-353. (doi:10.1007/BF02790137)

Cheng SY, Leonard JL \& Davis PJ 2010 Molecular aspects of thyroid hormone actions. Endocrine Reviews 31 139-170. (doi:10.1210/er.2009-0007)

Chopra IJ, Wu SY, Nakamura Y \& Solomon DH 1978 Monodeiodination of $3,5,3^{\prime}$-triiodothyronine and $3,3^{\prime}, 5^{\prime}$-triiodothyronine to $3,3^{\prime}$-diiodothyronine in vitro. Endocrinology 102 1099-1106. (doi:10.1210/endo-102-4-1099)

Chopra IJ, Sakane S \& Teco GN 1991 A study of the serum concentration of tumor necrosis factor-alpha in thyroidal and nonthyroidal illnesses. Journal of Clinical Endocrinology and Metabolism 72 1113-1116. (doi:10.1210/jcem-72$5-1113)$

Christoffolete MA, Arrojo e Drigo R, Gazoni F, Tente SM, Goncalves V, Amorim BS, Larsen PR, Bianco AC \& Zavacki AM 2007 Mice with impaired extrathyroidal thyroxine to $3,5,3^{\prime}$-triiodothyronine conversion maintain normal serum $3,5,3^{\prime}$-triiodothyronine concentrations.

Endocrinology 148 954-960. (doi:10.1210/en.2006-1042)

Contempre B, Dumont JE, Ngo B, Thilly CH, Diplock AT \& Vanderpas J 1991 Effect of selenium supplementation in hypothyroid subjects of an iodine and selenium deficient area: the possible danger of indiscriminate supplementation of iodine-deficient subjects with selenium. Journal of Clinical Endocrinology and Metabolism 73 213-215. (doi:10.1210/jcem73-1-213)

Contempre B, Duale NL, Dumont JE, Ngo B, Diplock AT \& Vanderpas J 1992 Effect of selenium supplementation on thyroid hormone metabolism in an iodine and selenium deficient population. Clinical Endocrinology 36 579-583. (doi:10.1111/j.1365-2265.1992.tb02268.x)

Cooper-Kazaz R, van der Deure W, Medici M, Visser TJ, Alkelai A, Glaser B, Peeters RP \& Lerer B 2009 Preliminary evidence that a functional 
polymorphism in type 1 deiodinase is associated with enhanced potentiation of the antidepressant effect of sertraline by triiodothyronine. Journal of Affective Disorders 116 113-116. (doi:10.1016/j.jad.2008.10.019) Corvilain B, Contempré B, Longombé AO, Goyens P, Gervy-Decoster C, Lamy F, Vanderpas JB \& Dumont JE 1993 Selenium and the thyroid: how the relationship was established. American Journal of Clinical Nutrition $\mathbf{5 7}$ 244S-248S

Cusin I, Rouru J, Visser T, Burger AG \& Rohner-Jeanrenaud F 2000 Involvement of thyroid hormones in the effect of intracerebroventricular leptin infusion on uncoupling protein-3 expression in rat muscle. Diabetes 49 1101-1105. (doi:10.2337/diabetes.49.7.1101)

Darras VM, Visser TJ, Berghman LR \& Kuhn ER 1992 Ontogeny of type I and type III deiodinase activities in embryonic and posthatch chicks: relationship with changes in plasma triiodothyronine and growth hormone levels. Comparative Biochemistry and Physiology. A, Comparative Physiology 103 131-136. (doi:10.1016/0300-9629(92)90252-L)

Davies PH, Black EG, Sheppard MC \& Franklyn JA 1996a Relation between serum interleukin-6 and thyroid hormone concentrations in 270 hospital in-patients with non-thyroidal illness. Clinical Endocrinology 44 199-205. (doi:10.1046/j.1365-2265.1996.668489.x)

Davies PH, Sheppard MC \& Franklyn JA $1996 b$ Regulation of type I $5^{\prime}$-deiodinase by thyroid hormone and dexamethasone in rat liver and kidney cells. Thyroid 6 221-228. (doi:10.1089/thy.1996.6.221)

Davies TF, Ando T, Lin RY, Tomer Y \& Latif R 2005 Thyrotropin receptorassociated diseases: from adenomata to Graves disease. Journal of Clinical Investigation 115 1972-1983. (doi:10.1172/JCI26031)

Debaveye Y, Ellger B, Mebis L, Darras VM \& Van den Berghe G 2008 Regulation of tissue iodothyronine deiodinase activity in a model of prolonged critical illness. Thyroid 18 551-560. (doi:10.1089/thy.2007.0287)

Debski MG, Pachucki J, Ambroziak M, Olszewski W \& Bar-Andziak E 2007 Human breast cancer tissue expresses high level of type $15^{\prime}$-deiodinase. Thyroid 17 3-10. (doi:10.1089/thy.2006.0012)

Dentice M, Ambrosio R \& Salvatore D 2009 Role of type 3 deiodinase in cancer. Expert Opinion on Therapeutic Targets 13 1363-1373. (doi:10.1517/ 14728220903339122)

DePalo D, Kinlaw WB, Zhao C, Engelberg-Kulka H \& St Germain DL 1994 Effect of selenium deficiency on type I $5^{\prime}$-deiodinase. Journal of Biological Chemistry 269 16223-16228.

Dora JM, Machado WE, Rheinheimer J, Crispim D \& Maia AL 2010 Association of the type 2 deiodinase Thr92Ala polymorphism with type 2 diabetes: case-control study and meta-analysis. European Journal of Endocrinology 163 427-434. (doi:10.1530/EJE-10-0419)

Doyle KP, Suchland KL, Ciesielski TM, Lessov NS, Grandy DK, Scanlan TS \& Stenzel-Poore MP 2007 Novel thyroxine derivatives, thyronamine and 3-iodothyronamine, induce transient hypothermia and marked neuroprotection against stroke injury. Stroke 38 2569-2576. (doi:10.1161/ STROKEAHA.106.480277)

Duntas LH 2010 Selenium and the thyroid: a close-knit connection. Journal of Clinical Endocrinology and Metabolism 95 5180-5188. (doi:10.1210/ jc.2010-0191)

Dutkiewicz S, Witeska A \& Nauman A 1995 The deiodination of thyroxine to triiodothyronine in the testes of patients with prostate cancer. International Urology and Nephrology 27 81-85. (doi:10.1007/BF02575224)

Galton VA, Schneider MJ, Clark AS \& St Germain DL 2009 Life without thyroxine to $3,5,3^{\prime}$-triiodothyronine conversion: studies in mice devoid of the 5'-deiodinases. Endocrinology 150 2957-2963. (doi:10.1210/en.2008-1572)

Garcia-Solis P \& Aceves C $20035^{\prime}$ Deiodinase in two breast cancer cell lines: effect of triiodothyronine, isoproterenol and retinoids. Molecular and Cellular Endocrinology 201 25-31. (doi:10.1016/S0303-7207(03) 00007-8)

Geffner DL, Azukizawa M \& Hershman JM 1975 Propylthiouracil blocks extrathyroidal conversion of thyroxine to triiodothyronine and augments thyrotropin secretion in man. Journal of Clinical Investigation 55 224-229. (doi:10.1172/JCI107925)

Gereben B, Goncalves C, Harney JW, Larsen PR \& Bianco AC 2000 Selective proteolysis of human type 2 deiodinase: a novel ubiquitin-proteasomal mediated mechanism for regulation of hormone activation. Molecular Endocrinology 14 1697-1708. (doi:10.1210/me.14.11.1697)
Goemann IM, Gereben B, Harney JW, Zhu B, Maia AL \& Larsen PR 2010 Substitution of serine for proline in the active center of type 2 iodothyronine deiodinase substantially alters its in vitro biochemical properties with dithiothreitol but not its function in intact cells. Endocrinology 151 821-829. (doi:10.1210/en.2009-0980)

Goswami A \& Rosenberg IN 1984 Iodothyronine 5'-deiodinase in rat kidney microsomes. Kinetic behavior at low substrate concentrations. Journal of Clinical Investigation 74 2097-2106. (doi:10.1172/JCI111634)

Goswami A \& Rosenberg IN 1987 Thioredoxin stimulates enzymatic outer ring monodeiodination of reverse triiodothronine. Endocrinology 121 1937-1945. (doi:10.1210/endo-121-6-1937)

Goyens P, Golstein J, Nsombola B, Vis H \& Dumont JE 1987 Selenium deficiency as a possible factor in the pathogenesis of myxoedematous endemic cretinism. Acta Endocrinologica 114 497-502. (doi:10.1530/acta.0.1140497)

Harris AR, Fang SL, Vagenakis AG \& Braverman LE 1978 Effect of starvation, nutriment replacement, and hypothyroidism on in vitro hepatic $\mathrm{T}_{4}$ to $\mathrm{T}_{3}$ conversion in the rat. Metabolism 27 1680-1690. (doi:10.1016/00260495(78)90290-1)

Huang TS, Chopra IJ, Boado R, Soloman DH \& Chua Teco GN 1988 Thyroxine inner ring monodeiodination activity in fetal tissues of the rat. Pediatric Research 23 196-199. (doi:10.1203/00006450-198802000-00014)

Inada M, Kasagi K, Kurata S, Kazama Y, Takayama H, Torizuka K, Fukase M \& Soma T 1975 Estimation of thyroxine and triiodothyronine distribution and of the conversion rate of thyroxine to triiodothyronine in man. Journal of Clinical Investigation 55 1337-1348. (doi:10.1172/JCI108053)

Ishii H, Inada M, Tanaka K, Mashio Y, Naito K, Nishikawa M, Matsuzuka F, Kuma K \& Imura H 1983 Induction of outer and inner ring monodeiodinases in human thyroid gland by thyrotropin. Journal of Clinical Endocrinology and Metabolism 57 500-505. (doi:10.1210/jcem-57-3-500)

Ito M, Toyoda N, Nomura E, Takamura Y, Amino N, Iwasaka T, Takamatsu J, Miyauchi A \& Nishikawa M 2011 Type 1 and type 2 iodothyronine deiodinases in the thyroid gland of patients with $3,5,3^{\prime}$-triiodothyroninepredominant Graves' disease. European Journal of Endocrinology 164 95-100. (doi:10.1530/EJE-10-0736)

Jakobs TC, Koehler MR, Schmutzler C, Glaser F, Schmid M \& Kohrle J 1997 a Structure of the human type I iodothyronine $5^{\prime}$-deiodinase gene and localization to chromosome 1p32-p33. Genomics 42 361-363. (doi:10. 1006/geno.1997.4736)

Jakobs TC, Schmutzler C, Meissner J \& Kohrle J $1997 b$ The promoter of the human type I $5^{\prime}$-deiodinase gene - mapping of the transcription start site and identification of a DR +4 thyroid-hormone-responsive element. European Journal of Biochemistry 247 288-297. (doi:10.1111/j.1432-1033. 1997.00288.x)

Jakobs TC, Mentrup B, Schmutzler C, Dreher I \& Kohrle J 2002 Proinflammatory cytokines inhibit the expression and function of human type I $5^{\prime}$-deiodinase in HepG2 hepatocarcinoma cells. European Journal of Endocrinology 146 559-566. (doi:10.1530/eje.0.1460559)

Janssen KP, Van Der Heide D, Visser TJ, Kaptein E \& Beynen AC 1994 Thyroid function and deiodinase activities in rats with marginal iodine deficiency. Biological Trace Element Research 40 237-246. (doi:10.1007/ BF02950796)

Jochum F, Terwolbeck K, Meinhold H, Behne D, Menzel H \& Lombeck I 1997 Effects of a low selenium state in patients with phenylketonuria. Acta Paediatrica 86 775-777. (doi:10.1111/j.1651-2227.1997.tb08587.x)

de Jong FJ, Peeters RP, den Heijer T, van der Deure WM, Hofman A, Uitterlinden AG, Visser TJ \& Breteler MM 2007 The association of polymorphisms in the type 1 and 2 deiodinase genes with circulating thyroid hormone parameters and atrophy of the medial temporal lobe. Journal of Clinical Endocrinology and Metabolism 92 636-640. (doi:10.1210/jc. 2006-1331)

Jorgensen JO, Pedersen SA, Laurberg P, Weeke J, Skakkebaek NE \& Christiansen JS 1989 Effects of growth hormone therapy on thyroid function of growth hormone-deficient adults with and without concomitant thyroxinesubstituted central hypothyroidism. Journal of Clinical Endocrinology and Metabolism 69 1127-1132. (doi:10.1210/jcem-69-6-1127)

Kaplan MM \& Utiger RD 1978 Iodothyronine metabolism in liver and kidney homogenates from hyperthyroid and hypothyroid rats. Endocrinology 103 156-161. (doi:10.1210/endo-103-1-156) 
Kaptein EM, Fisler JS, Duda MJ, Nicoloff JT \& Drenick EJ 1985 Relationship between the changes in serum thyroid hormone levels and protein status during prolonged protein supplemented caloric deprivation. Clinical Endocrinology 22 1-15. (doi:10.1111/j.1365-2265.1985.tb01059.x)

Kauf E, Dawczynski H, Jahreis G, Janitzky E \& Winnefeld K 1994 Sodium selenite therapy and thyroid-hormone status in cystic fibrosis and congenital hypothyroidism. Biological Trace Element Research 40 247-253. (doi:10.1007/ BF02950797)

Kester MH, Martinez de Mena R, Obregon MJ, Marinkovic D, Howatson A, Visser TJ, Hume R \& Morreale de Escobar G 2004 Iodothyronine levels in the human developing brain: major regulatory roles of iodothyronine deiodinases in different areas. Journal of Clinical Endocrinology and Metabolism 89 3117-3128. (doi:10.1210/jc.2003-031832)

Kim SW, Harney JW \& Larsen PR 1998 Studies of the hormonal regulation of type $25^{\prime}$-iodothyronine deiodinase messenger ribonucleic acid in pituitary tumor cells using semiquantitative reverse transcription-polymerase chain reaction. Endocrinology 139 4895-4905. (doi:10.1210/en.139.12.4895)

Koenig RJ 2005 Regulation of type 1 iodothyronine deiodinase in health and disease. Thyroid 15 835-840. (doi:10.1089/thy.2005.15.835)

Kohrle J 1997 Thyroid carcinoma: interrelationships between local thyroid hormone metabolism by the type I $5^{\prime}$-deiodinase and the expression of thyroid hormone receptors and other thyroid-specific (de-)differentiation markers. Current Topics in Pathology 91 83-116.

Kornasiewicz O, Debski M, Stepnowska M, Szalas A, Bar-Andziak E \& Krawczyk M 2010 The enzymatic activity of type 1 iodothyronine deiodinase (D1) is low in liver hemangioma: a preliminary study. Archivum Immunologiae et Therapiae Experimentalis 58 77-80. (doi:10.1007/s00005-009-0056-3)

Krohn K, Fuhrer D, Bayer Y, Eszlinger M, Brauer V, Neumann S \& Paschke R 2005 Molecular pathogenesis of euthyroid and toxic multinodular goiter. Endocrine Reviews 26 504-524. (doi:10.1210/er.2004-0005)

Kwakkel J, van Beeren HC, Ackermans MT, Platvoet-Ter Schiphorst MC, Fliers E, Wiersinga WM \& Boelen A 2009 Skeletal muscle deiodinase type 2 regulation during illness in mice. Journal of Endocrinology 203 263-270. (doi:10.1677/JOE-09-0118)

Larsen PR 1972 Triiodothyronine: review of recent studies of its physiology and pathophysiology in man. Metabolism 21 1073-1092. (doi:10.1016/ 0026-0495(72)90038-8)

Larsen PR, Silva JE \& Kaplan MM 1981 Relationships between circulating and intracellular thyroid hormones: physiological and clinical implications. Endocrine Reviews 2 87-102. (doi:10.1210/edrv-2-1-87)

Laurberg P 1978 Non-parallel variations in the preferential secretion of $3,5,3^{\prime}-$ triiodothyronine $\left(\mathrm{T}_{3}\right)$ and $3,3^{\prime}, 5^{\prime}$-triiodothyronine $\left(\mathrm{rT}_{3}\right)$ from dog thyroid. Endocrinology 102 757-766. (doi:10.1210/endo-102-3-757)

Laurberg P, Vestergaard H, Nielsen S, Christensen SE, Seefeldt T, Helleberg K \& Pedersen KM 2007 Sources of circulating 3,5,3'-triiodothyronine in hyperthyroidism estimated after blocking of type 1 and type 2 iodothyronine deiodinases. Journal of Clinical Endocrinology and Metabolism 92 2149-2156. (doi:10.1210/jc.2007-0178)

Laurberg P, Wallin G, Tallstedt L, Abraham-Nordling M, Lundell G \& Torring O 2008 TSH-receptor autoimmunity in Graves' disease after therapy with antithyroid drugs, surgery, or radioiodine: a 5-year prospective randomized study. European Journal of Endocrinology 158 69-75. (doi:10.1530/EJE-07-0450)

Legradi G, Emerson CH, Ahima RS, Flier JS \& Lechan RM 1997 Leptin prevents fasting-induced suppression of prothyrotropin-releasing hormone messenger ribonucleic acid in neurons of the hypothalamic paraventricular nucleus. Endocrinology 138 2569-2576. (doi:10.1210/en.138.6.2569)

Leonard JL \& Rosenberg IN 1980 Iodothyronine $5^{\prime}$-deiodinase from rat kidney: substrate specificity and the $5^{\prime}$-deiodination of reverse triiodothyronine. Endocrinology 107 1376-1383. (doi:10.1210/endo-107-5-1376)

Leonard JL \& Visser TJ 1986 Biochemistry of deiodination. In Thyroid Hormone Metabolism, pp 189-229. Ed. G Hennemann. New York: Marcel Dekker, Inc.

Leonard JL, Ekenbarger DM, Frank SJ, Farwell AP \& Koehrle J 1991 Localization of type I iodothyronine $5^{\prime}$-deiodinase to the basolateral plasma membrane in renal cortical epithelial cells. Journal of Biological Chemistry 266 11262-11269.

Leonard JL, Visser TJ \& Leonard DM 2001 Characterization of the subunit structure of the catalytically active type I iodothyronine deiodinase. Journal of Biological Chemistry 276 2600-2607. (doi:10.1074/jbc. M006973200)
Lombeck I, Jochum F \& Terwolbeck K 1996 Selenium status in infants and children with phenylketonuria and in maternal phenylketonuria. European Journal of Pediatrics 155 (Suppl 1) S140-S144. (doi:10.1007/PL00014232)

LoPresti JS, Eigen A, Kaptein E, Anderson KP, Spencer CA \& Nicoloff JT 1989 Alterations in $3,3^{\prime} 5^{\prime}$-triiodothyronine metabolism in response to propylthiouracil, dexamethasone, and thyroxine administration in man. Journal of Clinical Investigation 84 1650-1656. (doi:10.1172/JCI114343)

Lum SM, Nicoloff JT, Spencer CA \& Kaptein EM 1984 Peripheral tissue mechanism for maintenance of serum triiodothyronine values in a thyroxine-deficient state in man. Journal of Clinical Investigation 73 570-575. (doi:10.1172/JCI111245)

Macejova D, Liska J \& Brtko J 2001 Mammary gland carcinoma-related increase of type I iodothyronine $5^{\prime}$-deiodinase activity in Sprague-Dawley rats. General Physiology and Biophysics 20 293-302.

Maia AL 2007 Type 1 iodothyronine deiodinase is the major source of circulating $\mathrm{T}_{3}$ in hyperthyroidism: implications for therapy. Nature Clinical Practice. Endocrinology \& Metabolism 3 740-741. (doi:10.1038/ ncpendmet0619)

Maia AL, Berry MJ, Sabbag R, Harney JW \& Larsen PR 1995a Structural and functional differences in the dio1 gene in mice with inherited type 1 deiodinase deficiency. Molecular Endocrinology 9 969-980. (doi:10.1210/me. 9.8.969)

Maia AL, Harney JW \& Larsen PR 1995 b Pituitary cells respond to thyroid hormone by discrete, gene-specific pathways. Endocrinology 1361488 1494. (doi:10.1210/en.136.4.1488)

Maia AL, Kieffer JD, Harney JW \& Larsen PR 1995c Effect of 3,5,3'triiodothyronine $\left(\mathrm{T}_{3}\right)$ administration on dio1 gene expression and $\mathrm{T}_{3}$ metabolism in normal and type 1 deiodinase-deficient mice. Endocrinology 136 4842-4849. (doi:10.1210/en.136.11.4842)

Maia AL, Kim BW, Huang SA, Harney JW \& Larsen PR 2005 Type 2 iodothyronine deiodinase is the major source of plasma $T_{3}$ in euthyroid humans. Journal of Clinical Investigation 115 2524-2533. (doi:10.1172/ JCI25083)

Mandel SJ, Berry MJ, Kieffer JD, Harney JW, Warne RL \& Larsen PR 1992 Cloning and in vitro expression of the human selenoprotein, type I iodothyronine deiodinase. Journal of Clinical Endocrinology and Metabolism $\mathbf{7 5}$ 1133-1139. (doi:10.1210/jc.75.4.1133)

Meinhold H, Campos-Barros A \& Behne D 1992 Effects of selenium and iodine deficiency on iodothyronine deiodinases in brain, thyroid and peripheral tissue. Acta Medica Austriaca 19 (Suppl 1) 8-12.

Menjo M, Murata Y, Fujii T, Nimura Y \& Seo H 1993 Effects of thyroid and glucocorticoid hormones on the level of messenger ribonucleic acid for iodothyronine type $\mathrm{I} 5^{\prime}$-deiodinase in rat primary hepatocyte cultures grown as spheroids. Endocrinology 133 2984-2990. (doi:10.1210/en.133.6.2984)

Meyer EL, Wagner MS \& Maia AL 2007 Iodothyronine deiodinases expression in thyroid neoplasias. Arquivos Brasileiros de Endocrinologia e Metabologia 51 690-700. (doi:10.1590/S0004-27302007000500006)

Mol JA \& Visser TJ 1985 Rapid and selective inner ring deiodination of thyroxine sulfate by rat liver deiodinase. Endocrinology 117 8-12. (doi:10. 1210/endo-117-1-8)

Mori K, Stone S, Braverman LE \& Devito WJ 1996 Involvement of tyrosine phosphorylation in the regulation of 5 '-deiodinases in FRTL-5 rat thyroid cells and rat astrocytes. Endocrinology 137 1313-1318. (doi:10.1210/en.137.4.1313)

Nagaya T, Fujieda M, Otsuka G, Yang JP, Okamoto T \& Seo H 2000 A potential role of activated NF-kappa B in the pathogenesis of euthyroid sick syndrome. Journal of Clinical Investigation 106 393-402. (doi:10.1172/JCI7771)

Nakamura H, Noh JY, Itoh K, Fukata S, Miyauchi A \& Hamada N 2007 Comparison of methimazole and propylthiouracil in patients with hyperthyroidism caused by Graves' disease. Journal of Clinical Endocrinology and metabolism 92 2157-2162. (doi:10.1210/jc.2006-2135)

Nicoloff JT, Low JC, Dussault JH \& Fisher DA 1972 Simultaneous measurement of thyroxine and triiodothyronine peripheral turnover kinetics in man. Journal of Clinical Investigation 51 473-483. (doi:10.1172/ JCI106835)

Nishikawa M, Toyoda N, Yonemoto T, Ogawa Y, Tabata S, Sakaguchi N, Tokoro T, Gondou A, Yoshimura M, Yoshikawa N et al. 1998 Quantitative measurements for type 1 deiodinase messenger ribonucleic acid in human 
peripheral blood mononuclear cells: mechanism of the preferential increase of $\mathrm{T}_{3}$ in hyperthyroid Graves' disease. Biochemical and Biophysical Research Communications 250 642-646. (doi:10.1006/bbrc.1998.9358)

Ohguchi H, Tanaka T, Uchida A, Magoori K, Kudo H, Kim I, Daigo K, Sakakibara I, Okamura M, Harigae H et al. 2008 Hepatocyte nuclear factor 4alpha contributes to thyroid hormone homeostasis by cooperatively regulating the type 1 iodothyronine deiodinase gene with GATA4 and Kruppel-like transcription factor 9. Molecular and Cellular Biology 28 3917-3931. (doi:10.1128/MCB.02154-07)

Olivares EL, Marassi MP, Fortunato RS, da Silva AC, Costa-e-Sousa RH, Araujo IG, Mattos EC, Masuda MO, Mulcahey MA, Huang SA et al. 2007 Thyroid function disturbance and type 3 iodothyronine deiodinase induction after myocardial infarction in rats a time course study. Endocrinology 148 4786-4792. (doi:10.1210/en.2007-0043)

O'Mara BA, Dittrich W, Lauterio TJ \& St Germain DL 1993 Pretranslational regulation of type I $5^{\prime}$-deiodinase by thyroid hormones and in fasted and diabetic rats. Endocrinology 133 1715-1723. (doi:10.1210/en.133.4.1715)

Otten MH, Mol JA \& Visser TJ 1983 Sulfation preceding deiodination of iodothyronines in rat hepatocytes. Science 221 81-83. (doi:10.1126/science. 6857270)

Otten MH, Hennemann G, Docter R \& Visser TJ 1984 Metabolism of $3,3^{\prime}$-diiodothyronine in rat hepatocytes: interaction of sulfation with deiodination. Endocrinology 115 887-894. (doi:10.1210/endo-115-3-887)

Pachucki J, Ambroziak M, Tanski Z, Luczak J, Nauman J \& Nauman A 2001 Type I $5^{\prime}$-iodothyronine deiodinase activity and mRNA are remarkably reduced in renal clear cell carcinoma. Journal of Endocrinological Investigation 24 253-261.

Panicker V, Cluett C, Shields B, Murray A, Parnell KS, Perry JR, Weedon MN, Singleton A, Hernandez D, Evans J et al. 2008 A common variation in deiodinase 1 gene DIO1 is associated with the relative levels of free thyroxine and triiodothyronine. Journal of Clinical Endocrinology and Metabolism 93 3075-3081. (doi:10.1210/jc.2008-0397)

Peeters RP, van Toor H, Klootwijk W, de Rijke YB, Kuiper GG, Uitterlinden AG \& Visser TJ 2003a Polymorphisms in thyroid hormone pathway genes are associated with plasma TSH and iodothyronine levels in healthy subjects. Journal of Clinical Endocrinology and Metabolism 88 2880-2888. (doi:10.1210/jc.2002-021592)

Peeters RP, Wouters PJ, Kaptein E, van Toor H, Visser TJ \& Van den Berghe G $2003 b$ Reduced activation and increased inactivation of thyroid hormone in tissues of critically ill patients. Journal of Clinical Endocrinology and Metabolism 88 3202-3211. (doi:10.1210/jc.2002-022013)

Peeters RP, van den Beld AW, van Toor H, Uitterlinden AG, Janssen JA, Lamberts SW \& Visser TJ 2005a A polymorphism in type I deiodinase is associated with circulating free insulin-like growth factor I levels and body composition in humans. Journal of Clinical Endocrinology and Metabolism 90 256-263. (doi:10.1210/jc.2004-1301)

Peeters RP, van der Geyten S, Wouters PJ, Darras VM, van Toor H, Kaptein E, Visser TJ \& Van den Berghe G $2005 b$ Tissue thyroid hormone levels in critical illness. Journal of Clinical Endocrinology and Metabolism 90 6498-6507. (doi:10.1210/jc.2005-1013)

Peeters RP, Wouters PJ, van Toor H, Kaptein E, Visser TJ \& Van den Berghe G 2005 c Serum $3,3^{\prime}, 5^{\prime}$-triiodothyronine $\left(\mathrm{rT}_{3}\right)$ and $3,5,3^{\prime}$-triiodothyronine/ $\mathrm{rT}_{3}$ are prognostic markers in critically ill patients and are associated with postmortem tissue deiodinase activities. Journal of Clinical Endocrinology and Metabolism 90 4559-4565. (doi:10.1210/jc.2005-0535)

Peeters RP, van der Deure WM \& Visser TJ 2006 Genetic variation in thyroid hormone pathway genes; polymorphisms in the TSH receptor and the iodothyronine deiodinases. European Journal of Endocrinology 155 655-662. (doi:10.1530/eje.1.02279)

Pekary AE, Berg L, Santini F, Chopra I \& Hershman JM 1994 Cytokines modulate type I iodothyronine deiodinase mRNA levels and enzyme activity in FRTL-5 rat thyroid cells. Molecular and Cellular Endocrinology 101 R31-R35. (doi:10.1016/0303-7207(94)90256-9)

Piehl S, Heberer T, Balizs G, Scanlan TS, Smits R, Koksch B \& Köhrle J 2008 Thyronamines are isozyme-specific substrates of deiodinases. Endocrinology 149 3037-3045. (doi:10.1210/en.2007-1678)
Piekielko-Witkowska A, Master A, Wojcicka A, Boguslawska J, Brozda I, Tanski Z \& Nauman A 2009 Disturbed expression of type 1 iodothyronine deiodinase splice variants in human renal cancer. Thyroid 19 1105-1113. (doi:10.1089/thy.2008.0284)

Portnay GI, O’Brian JT, Bush J, Vagenakis AG, Azizi F, Arky RA, Ingbar SH \& Braverman LE 1974 The effect of starvation on the concentration and binding of thyroxine and triiodothyronine in serum and on the response to TRH. Journal of Clinical Endocrinology and Metabolism 39 191-194. (doi:10.1210/jcem-39-1-191)

Richard K, Hume R, Kaptein E, Sanders JP, van Toor H, De Herder WW, den Hollander JC, Krenning EP \& Visser TJ 1998 Ontogeny of iodothyronine deiodinases in human liver. Journal of Clinical Endocrinology and Metabolism 83 2868-2874. (doi:10.1210/jc.83.8.2868)

Riesco G, Taurog A \& Larsen PR 1976 Variations in the response of the thyroid gland of the rat to different low-iodine diets: correlation with iodine content of diet. Endocrinology 99 270-280. (doi:10.1210/endo-99-1-270)

Rodriguez-Perez A, Palos-Paz F, Kaptein E, Visser TJ, Dominguez-Gerpe L, Alvarez-Escudero J \& Lado-Abeal J 2008 Identification of molecular mechanisms related to nonthyroidal illness syndrome in skeletal muscle and adipose tissue from patients with septic shock. Clinical Endocrinology 68 821-827. (doi:10.1111/j.1365-2265.2007.03102.x)

Rosenbaum M, Goldsmith R, Bloomfield D, Magnano A, Weimer L, Heymsfield S, Gallagher D, Mayer L, Murphy E \& Leibel RL 2005 Low-dose leptin reverses skeletal muscle, autonomic, and neuroendocrine adaptations to maintenance of reduced weight. Journal of Clinical Investigation 115 3579-3586. (doi:10.1172/JCI25977)

Sabatino L, Iervasi G, Ferrazzi P, Francesconi D \& Chopra IJ 2000 A study of iodothyronine $5^{\prime}$-monodeiodinase activities in normal and pathological tissues in man and their comparison with activities in rat tissues. Life Sciences 68 191-202. (doi:10.1016/S0024-3205(00)00929-2)

Saberi M, Sterling FH \& Utiger RD 1975 Reduction in extrathyroidal triiodothyronine production by propylthiouracil in man. Journal of Clinical Investigation 55 218-223. (doi:10.1172/JCI107924)

Salvatore D, Tu H, Harney JW \& Larsen PR 1996 Type 2 iodothyronine deiodinase is highly expressed in human thyroid. Journal of Clinical Investigation 98 962-968. (doi:10.1172/JCI118880)

Sanders JP, Van der Geyten S, Kaptein E, Darras VM, Kuhn ER, Leonard JL \& Visser TJ 1997 Characterization of a propylthiouracil-insensitive type I iodothyronine deiodinase. Endocrinology 138 5153-5160. (doi:10.1210/en. 138.12.5153)

Santini F, Chiovato L, Ghirri P, Lapi P, Mammoli C, Montanelli L, Scartabelli G, Ceccarini G, Coccoli L, Chopra IJ et al. 1999 Serum iodothyronines in the human fetus and the newborn: evidence for an important role of placenta in fetal thyroid hormone homeostasis. Journal of Clinical Endocrinology and Metabolism 84 493-498. (doi:10.1210/jc.84.2.493)

Scanlan TS 2009 Minireview: 3-iodothyronamine (T1AM): a new player on the thyroid endocrine team? Endocrinology 150 1108-1111. (doi:10.1210/ en.2008-1596)

Scanlan TS, Suchland KL, Hart ME, Chiellini G, Huang Y, Kruzich PJ, Frascatelli S, Crossley DA II, Bunzow JR, Ronca-Testoni S et al. 2004 3 -Iodothyronamine is an endogenous and rapid-acting derivative of thyroid hormone. Nature Medicine 10 638-642. (doi:10.1038/nm1051)

Schmutzler C, Hoang-Vu C, Ruger B \& Kohrle J 2004 Human thyroid carcinoma cell lines show different retinoic acid receptor repertoires and retinoid responses. European Journal of Endocrinology 150 547-556. (doi:10.1530/eje.0.1500547)

Schneider MJ, Fiering SN, Thai B, Wu SY, St Germain E, Parlow AF, St Germain DL \& Galton VA 2006 Targeted disruption of the type 1 selenodeiodinase gene (Dio1) results in marked changes in thyroid hormone economy in mice. Endocrinology 147 580-589. (doi:10.1210/ en.2005-0739)

Schoenmakers CH, Pigmans IG, Poland A \& Visser TJ 1993 Impairment of the selenoenzyme type I iodothyronine deiodinase in $\mathrm{C} 3 \mathrm{H} / \mathrm{He}$ mice. Endocrinology 132 357-361. (doi:10.1210/en.132.1.357)

Schoenmakers CH, Pigmans IG \& Visser TJ 1995 Investigation of type I and type III iodothyronine deiodinases in rat tissues using $\mathrm{N}$-bromoacetyliodothyronine affinity labels. Molecular and Cellular Endocrinology 107 173-180. (doi:10.1016/0303-7207(94)03440-5) 
Schreck R, Schnieders F, Schmutzler C \& Kohrle J 1994 Retinoids stimulate type I iodothyronine $5^{\prime}$-deiodinase activity in human follicular thyroid carcinoma cell lines. Journal of Clinical Endocrinology and Metabolism 79 791-798. (doi:10.1210/jc.79.3.791)

Schröder-van der Elst JP, van der Heide D, Morreale de Escobar G \& Obregón MJ 1998 Iodothyronine deiodinase activities in fetal rat tissues at several levels of iodine deficiency: a role for the skin in 3,5,3'-triiodothyronine economy? Endocrinology 139 2229-2234. (doi:10.1210/en.139.5.2229)

Sharifi J \& St Germain DL 1992 The cDNA for the type I iodothyronine $5^{\prime}$-deiodinase encodes an enzyme manifesting both high $K_{\mathrm{m}}$ and low $K_{\mathrm{m}}$ activity. Evidence that rat liver and kidney contain a single enzyme which converts thyroxine to 3,5,3'-triiodothyronine. Journal of Biological Chemistry 267 12539-12544.

Simonides WS, Mulcahey MA, Redout EM, Muller A, Zuidwijk MJ, Visser TJ, Wassen FW, Crescenzi A, da-Silva WS, Harney J et al. 2008 Hypoxia-inducible factor induces local thyroid hormone inactivation during hypoxic-ischemic disease in rats. Journal of Clinical Investigation 118 975-983. (doi:10.1172/JCI32824)

de Souza Meyer EL, Dora JM, Wagner MS \& Maia AL 2005 Decreased type 1 iodothyronine deiodinase expression might be an early and discrete event in thyroid cell dedifferentiation towards papillary carcinoma. Clinical Endocrinology 62 672-678. (doi:10.1111/j.1365-2265.2005.02277.x)

St Germain DL 1988 The effects and interactions of substrates, inhibitors, and the cellular thiol-disulfide balance on the regulation of type II iodothyronine 5'-deiodinase. Endocrinology 122 1860-1868. (doi:10.1210/ endo-122-5-1860)

St Germain DL \& Croteau W 1989 Ligand-induced inactivation of type I iodothyronine $5^{\prime}$-deiodinase: protection by propylthiouracil in vivo and reversibility in vitro. Endocrinology 125 2735-2744. (doi:10.1210/endo-1255-2735)

St Germain DL \& Galton VA 1985 Comparative study of pituitary-thyroid hormone economy in fasting and hypothyroid rats. Journal of Clinical Investigation 75 679-688. (doi:10.1172/JCI111747)

St Germain DL \& Galton VA 1997 The deiodinase family of selenoproteins. Thyroid 7 655-668. (doi:10.1089/thy.1997.7.655)

Sun BC, Harney JW, Berry MJ \& Larsen PR 1997 The role of the active site cysteine in catalysis by type 1 iodothyronine deiodinase. Endocrinology $\mathbf{1 3 8}$ 5452-5458. (doi:10.1210/en.138.12.5452)

Tannahill LA, Visser TJ, McCabe CJ, Kachilele S, Boelaert K, Sheppard MC, Franklyn JA \& Gittoes NJ 2002 Dysregulation of iodothyronine deiodinase enzyme expression and function in human pituitary tumours. Clinical Endocrinology 56 735-743. (doi:10.1046/j.1365-2265.2002.01541.x)

Tegler L, Anderberg B \& Smeds S 1982 Preferential secretion of triiodothyronine in man. Hormone and Metabolic Research 14 593-595. (doi:10.1055/s-2007-1019089)

Torpy DJ, Tsigos C, Lotsikas AJ, Defensor R, Chrousos GP \& Papanicolaou DA 1998 Acute and delayed effects of a single-dose injection of interleukin6 on thyroid function in healthy humans. Metabolism 47 1289-1293. (doi:10.1016/S0026-0495(98)90338-9)

Toyoda N, Nishikawa M, Mori Y, Yoshimura M, Masaki H, Gondou A, Yonemoto T \& Inada M 1992 Identification of a 27-kilodalton protein with the properties of type I iodothyronine $5^{\prime}$-deiodinase in human thyroid gland. Journal of Clinical Endocrinology and Metabolism 74 533-538. (doi:10. $1210 /$ jc.74.3.533)

Toyoda N, Zavacki AM, Maia AL, Harney JW \& Larsen PR 1995 A novel retinoid $\mathrm{X}$ receptor-independent thyroid hormone response element is present in the human type 1 deiodinase gene. Molecular and Cellular Biology 15 5100-5112.

Toyoda N, Kaptein E, Berry MJ, Harney JW, Larsen PR \& Visser TJ 1997 Structure-activity relationships for thyroid hormone deiodination by mammalian type I iodothyronine deiodinases. Endocrinology 138 213-219. (doi:10.1210/en.138.1.213)

Van der Deure WM, Hansen PS, Peeters RP, Uitterlinden AG, Fenger M, Kyvik KO, Hegedüs L \& Visser TJ 2009 The effect of genetic variation in the type 1 deiodinase gene on the interindividual variation in serum thyroid hormone levels: an investigation in healthy Danish twins. Clinical Endocrinology 70 954-960. (doi:10.1111/j.1365-2265.2008.03420.x)
Van der Geyten S, Buys N, Sanders JP, Decuypere E, Visser TJ, Kuhn ER \& Darras VM 1999 Acute pretranslational regulation of type III iodothyronine deiodinase by growth hormone and dexamethasone in chicken embryos. Molecular and Cellular Endocrinology 147 49-56. (doi:10.1016/S03037207(98)00218-4)

Van der Geyten S, Byamungu N, Reyns GE, Kuhn ER \& Darras VM 2005 Iodothyronine deiodinases and the control of plasma and tissue thyroid hormone levels in hyperthyroid tilapia (Oreochromis niloticus). Journal of Endocrinology 184 467-479. (doi:10.1677/joe.1.05986)

Vanderpas JB, Contempre B, Duale NL, Goossens W, Bebe N, Thorpe R, Ntambue K, Dumont J, Thilly CH \& Diplock AT 1990 Iodine and selenium deficiency associated with cretinism in northern Zaire. American Journal of Clinical Nutrition 52 1087-1093.

Vignati L, Finley RJ, Hagg S \& Aoki TT 1978 Protein conservation during prolonged fast: a function of triiodothyronine levels. Transactions of the Association of American Physicians 91 169-179.

Visser TJ, Does-Tobe I, Docter R \& Hennemann G 1976 Subcellular localization of a rat liver enzyme converting thyroxine into triiodothyronine and possible involvement of essential thiol groups. Biochemical Journal 157 479-482.

Visser TJ, Fekkes D, Docter R \& Hennemann G 1978 Sequential deiodination of thyroxine in rat liver homogenate. Biochemical Journal 174 221-229.

Visser TJ, Fekkes D, Docter R \& Hennemann G 1979 Kinetics of enzymic reductive deiodination of iodothyronines. Effect of $\mathrm{pH}$. Biochemical Journal 179 489-495.

Visser TJ, Kaptein E, Terpstra OT \& Krenning EP 1988 Deiodination of thyroid hormone by human liver. Journal of Clinical Endocrinology and Metabolism 67 17-24. (doi:10.1210/jcem-67-1-17)

Wagner MS, Wajner SM, Dora JM \& Maia AL 2007 Regulation of Dio2 gene expression by thyroid hormones in normal and type 1 deiodinase-deficient C3H mice. Journal of Endocrinology 193 435-444. (doi:10.1677/JOE-070099)

Wagner MS, Wajner SM \& Maia AL 2008 The role of thyroid hormone in testicular development and function. Journal of Endocrinology 199 351-365. (doi:10.1677/JOE-08-0218)

Warner MH \& Beckett GJ 2010 Mechanisms behind the non-thyroidal illness syndrome: an update. Journal of Endocrinology 205 1-13. (doi:10.1677/JOE09-0412)

Wawrzynska L, Sakowicz A, Rudzinski P, Langfort R \& Kurzyna M 2003 The conversion of thyroxine to triiodothyronine in the lung: comparison of activity of type I iodothyronine $5^{\prime}$ deiodinase in lung cancer with peripheral lung tissues. Monaldi Archives for Chest Disease 59 140-145.

Woeber KA 2006 Triiodothyronine production in Graves' hyperthyroidism. Thyroid 16 687-690. (doi:10.1089/thy.2006.16.687)

Yang XF, Hou XH, Xu J, Guo HL, Yinq CJ, Chen XY \& Sun XF 2006 Effect of selenium supplementation on activity and mRNA expression of type 1 deiodinase in mice with excessive iodine intake. Biomedical and Environmental Sciences 19 302-308.

Yu J \& Koenig RJ 2000 Regulation of hepatocyte thyroxine 5 '-deiodinase by $\mathrm{T}_{3}$ and nuclear receptor coactivators as a model of the sick euthyroid syndrome. Journal of Biological Chemistry 275 38296-38301. (doi:10.1074/ jbc.M004866200)

Yu J \& Koenig RJ 2006 Induction of type 1 iodothyronine deiodinase to prevent the nonthyroidal illness syndrome in mice. Endocrinology 147 3580-3585. (doi:10.1210/en.2005-1443)

Zhang CY, Kim S, Harney JW \& Larsen PR 1998 Further characterization of thyroid hormone response elements in the human type 1 iodothyronine deiodinase gene. Endocrinology 139 1156-1163. (doi:10.1210/en.139.3.1156)

\section{Received in final form 15 March 2011 \\ Accepted 17 March 2011 Made available online as an Accepted Preprint 17 March 2011}

